Andrews University

Digital Commons @ Andrews University

\title{
El Evangelismo de la Amistad Como Factor de Crecimiento en la Iglesia Adventista del Séptimo Día
}

Tomas Torres de Dios

Andrews University

Follow this and additional works at: https://digitalcommons.andrews.edu/dmin

Part of the Practical Theology Commons

\section{Recommended Citation}

Torres de Dios, Tomas, "El Evangelismo de la Amistad Como Factor de Crecimiento en la Iglesia Adventista del Séptimo Día" (2002). Professional Dissertations DMin. 606.

https://dx.doi.org/10.32597/dmin/606

https://digitalcommons.andrews.edu/dmin/606

This Project Report is brought to you for free and open access by the Graduate Research at Digital Commons @ Andrews University. It has been accepted for inclusion in Professional Dissertations DMin by an authorized administrator of Digital Commons @ Andrews University. For more information, please contact repository@andrews.edu. 


\begin{abstract}
FRIENDSHIP EVANGELISM AS A CHURCH GROWTH FACTOR IN THE SEVENTH-DAY ADVENTIST CHURCH
\end{abstract}

by

Tomás Torres de Dios

Adviser: Nancy Jean Vyhmeister 


\title{
ABSTRACT OF GRADUATE STUDENT RESEARCH
}

\author{
Dissertation
}

\author{
Andrews University \\ Seventh-day Adventist Theological Seminary \\ Montemorelos Extension
}

Title: FRIENDSHIP EVANGELISM AS A CHURCH GROWTH FACTOR IN THE SEVENTH-DAY ADVENTIST CHURCH

Name of researcher: Tomás Torres de Dios

Name and degree of faculty adviser: Nancy Jean Vyhmeister, Ed.D.

Date completed: July 2002

The faithful fulfillment of the gospel commission demands the use of correct and appropriate methods to bring new members into the church. For this reason, the Seventhday Adventist Church has used various evangelistic methods. The purpose of this dissertation was to make a theoretical study of friendship evangelism and prepare a workshop to train church members and local leaders.

The Bible shows kindness as one of God's attributes in dealing with human beings. Ever since Creation God has provided what human beings need to live in an environment of good relationships. One of the ways in which God showed kindness was giving Adam a companion to establish a perfect relationship. 
This virtue of God's character has been manifested throughout the history of his people in many ways, as he showed his kindness and goodwill toward them. The miraculous provision of manna, the powerful liberation from Egyptian slavery, the provision of water in the desert are but samples of God's gracious character. The death of Christ as a ransom for humanity is the culminating demonstration of divine goodness.

Ellen G. White comments frequently on this characteristic of God towards his children, showing it as a model of the kindness and good relations that should exist among human beings. In addition, she presents kindness as a means for establishing friendly relationships which can be used as a method of evangelism.

Research shows that approximately 60 percent of those who join a church had their first contact through an Adventist friend, neighbor or relative. The growth of the apostolic church and the spread of the gospel at that time was due, in a great measure, to the friendly relationships established by apostles and members.

The implementation of a program of friendship evangelism in each church can help to bring in new members. For this reason, a six-hour workshop on friendship evangelism was designed for church members and leaders. The workshop can be offered at the local church level, in a church district, or even to all the pastors in a given territory.

The workshop materials appear in the appendix of the dissertation. The plan proposed will not only help church members to do friendship evangelism, it will also make the church a friendlier place. 


\section{SÍNTESIS}

EL EVANGELISMO DE LA AMISTAD COMO

FACTOR DE CRECIMIENTO EN LA IGLESIA ADVENTISTA DEL SÉPTIMO DÍA

por

Tomás Torres de Dios

Asesora: Nancy W. de Vyhmeister 


\section{SÍNTESIS DE TESIS DOCTORAL}

Andrews University

Seventh-day Adventist Theological Seminary

Extensión Montemorelos

Título: EL EVANGELISMO DE LA AMISTAD COMO FACTOR DE CRECIMIENTO EN LA IGLESIA ADVENTISTA DEL SÉPTIMO DÍA

Nombre del investigador: Tomás Torres de Dios

Nombre y grado de la asesora: Nancy Vyhmeister, Ed. D.

Fecha de terminación: Julio 2002

El cumplimiento fiel de la comisión evangélica exige el uso de métodos correctos y adecuados para lograr la conquista de nuevos miembros que formen parte de la iglesia. Por esta razón, la Iglesia Adventista del Séptimo Día, en el deseo de cumplir con este cometido ha utilizado diversas maneras de evangelización. El propósito de esta tesis fue realizar un estudio teórico del evangelismo de la amistad y preparar un seminario de adiestramiento para miembros y dirigentes de la iglesia.

La Biblia muestra la bondad como uno de los atributos de Dios al tratar a los seres humanos. Desde la misma creación el Señor proveyó lo necesario para que la raza humana viviera en un ambiente de buenas relaciones humanas. Una de las maneras como lo manifestó fue otorgándole a Adán una compañera para establecer una relación perfecta de compañerismo. 
Esta virtud del carácter de Dios se ve manifestada a lo largo de la historia de su pueblo, en las diversas formas, como les muestra un trato amable y bondadoso. La provisión milagrosa de alimento a través del maná, la liberación poderosa de la esclavitud egipcia, la provisión de agua en el desierto, la misma muerte de Jesús como rescate por la humanidad son demostraciones de su bondad y amabilidad divina.

Elena G. de White comenta ampliamente esta característica de Dios hacia sus hijos, presentándola como un modelo de amabilidad y buen trato que debe existir entre los seres humanos. Además presenta la amabilidad como un medio para establecer relaciones amistosas, las cuales pueden ser utilizadas como medio de evangelización.

Los estudios realizados demuestran que aproximadamente un 60 por ciento de las personas que ingresan a la iglesia tuvieron un contacto con algún amigo, vecino o conocido adventista. El crecimiento numérico de la iglesia primitiva y la propagación del evangelio se debió en gran medida a las relaciones amistosas establecidas por los apóstoles y miembros.

El estudio realizado indica que implementar un programa de evangelismo por la amistad en cada iglesia es un elemento útil para la ganancia de nuevos miembros. Por lo tanto se diseñó un seminario de seis horas para miembros y dirigentes de la iglesia. El seminario se puede dar a nivel iglesia local, a nivel de distrito o bien a todos los pastores y dirigentes de la asociación o misión.

El plan propuesto en esta tesis ayudará no sólo a evangelizar por medio de la amistad, sino que permitirá que la iglesia sea más amistosa. 


\title{
Andrews University \\ Seventh-day Adventist Theological Seminary \\ Extensión Montemorelos \\ EL EVANGELISMO DE LA AMISTAD COMO FACTOR DE CRECIMIENTO EN LA IGLESIA ADVENTISTA DEL SÉPTIMO DÍA
}

\author{
Tesis \\ presentada en cumplimiento parcial \\ de los requisitos para el grado de \\ Doctor en Ministerio \\ por \\ Tomás Torres de Dios \\ Julio de 2002
}



EL EVANGELISMO DE LA AMISTAD COMO FACTOR DE CRECIMIENTO EN LA IGLESIA ADVENTISTA

Tesis

presentada en cumplimiento parcial de los requisitos para el grado de Doctor en Ministerio

por

Tomás Torres de Dios

APROBADO POR:
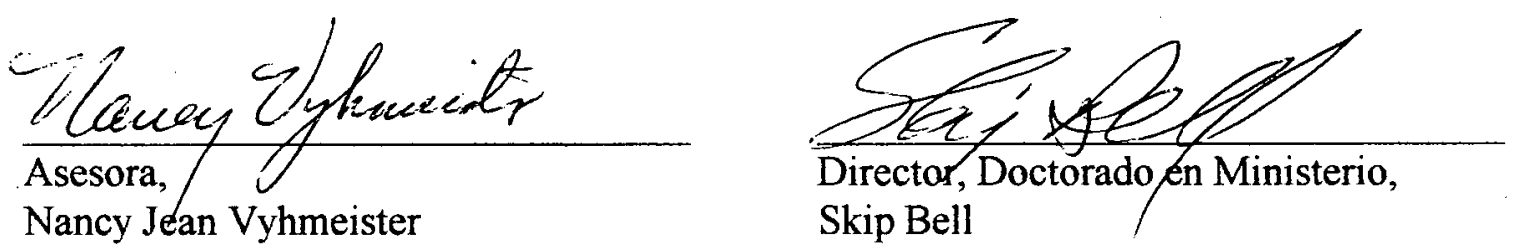

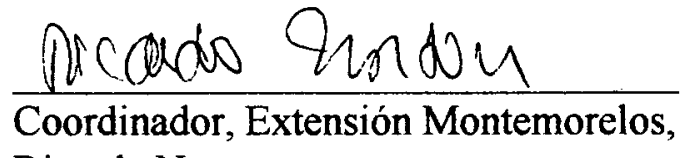
Ricardo Norton

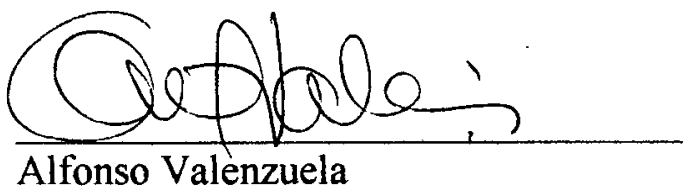

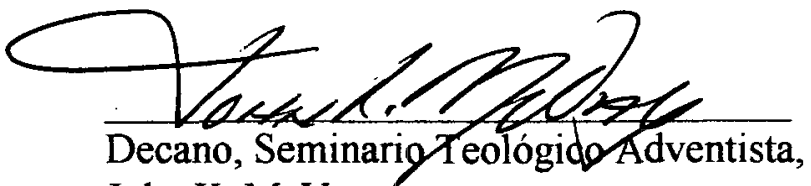

John K. McVay

December 2, 2002

Fecha de aprobación 
A mi esposa María Lourdes y a mis hijos Esli Josué y Esli Caleb por su apoyo y comprensión en la realización de este proyecto. 


\section{ÍNDICE DE CONTENIDO}

Capítulo

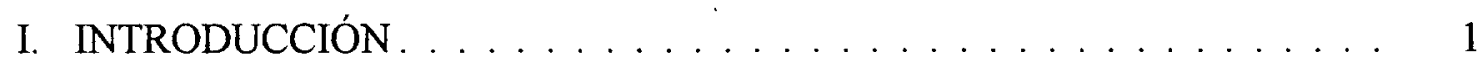

Propósito del proyecto . . . . . . . . . . . . . . . . . . . 1

Justificación del proyecto . . . . . . . . ........ 2

Limitaciones del proyecto . . . . . . . . . . . . . . . . 2

Descripción del proyecto. . . . . . . . . . ...... 2

II. FUNDAMENTOS TEÓRICOS DE LA AMABILIDAD . . . . . . . . . . . . . 4

La amabilidad en la Biblia. . . . . . . . . . . . . . . . . . . 5

Antiguo Testamento . . . . . . . . . . . . . . . . 5

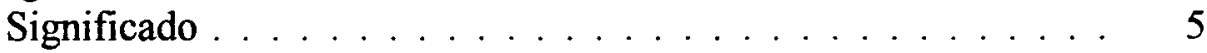

Ejemplos bíblicos de amabilidad. . . . . . . . . . . . . 6

Principios bíblicos de la amabilidad. . . . . . . . . . . . . 8

Origen de la amabilidad . . . . . . . . . . . . . . . . . . . 9

Nuevo Testamento . . . . . . . . . . . . . . . . . . . . . 10

Significado . . . . . . . . . . . . . . . . . . 10

La amabilidad en los escritos de Pablo . . . . . . . . . . . . . 12

La amabilidad en los escritos de Elena G. de White. . . . . . . . . . . . 13

Importancia en las relaciones humanas. . . . . . . . . . . . . 13

Importancia en la religión . . . . . . . . . . . . . . . . . 14

Como medio de evangelismo . . . . . . . . . . . . . . . . 16

Con palabras y actos amables . . . . . . . . . . . . 16

Con disposición al servicio amable . . . . . . . . . . . . . 18

Con una amistad amable. . . . . . . . . . . . . . . . . 19

La amabilidad según otros autores . . . . . . . . . . . . . . . 21

Sujeta a las circunstancias . . . . . . . . . . . . . . . 21

Código de conducta . . . . . . . . . . . . . . . . 22

Conjunto de deberes positivos . . . . . . . . . . . . . 23

III. EL EVANGELISMO DE LA AMISTAD . . . . . . . . . . . . . . . . . . 26

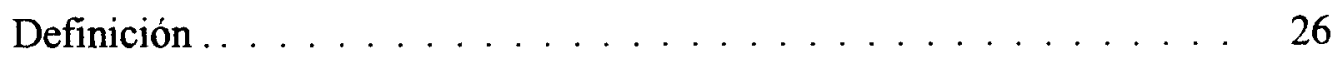

Base para el método del evangelismo de la amistad. . . . . . . . . . . . . 27

Ejemplos bíblicos . . . . . . . . . . . . . . . . . . . 29

La amistad como paso en la evangelización. . . . . . . . . . . . . 31

Importancia del compañerismo cristiano. . . . . . . . . . . . . 34 
Preparación para realizar el evangelismo de la amistad . . . . . . . 37

Maneras prácticas para la evangelización por la amistad . . . . . . . . 39

IV. PROGRAMA DE EVANGELIZACIÓN POR LA AMISTAD $\ldots \ldots \ldots . .43$

Preparación del programa $\ldots \ldots \ldots \ldots \ldots \ldots \ldots \ldots . \ldots \ldots$

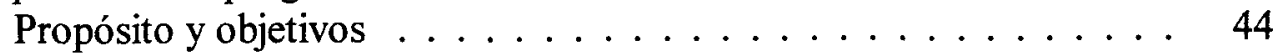

Planeamiento . . . . . . . . . . . . . . . . 45

Autorización de las juntas correspondientes . . . . . . . . . 45

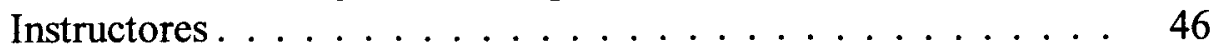

Quiénes tomarán el curso. . . . . . . . . . . . . . 46

Lugar, materiales y equipo. . . . . . . . . . . . . . 46

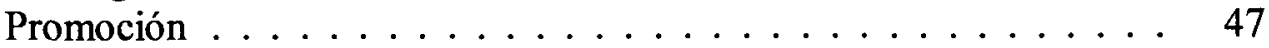

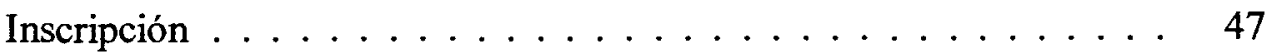

Implementación $\ldots \ldots \ldots \ldots \ldots \ldots \ldots \ldots \ldots \ldots$

Desarrollo del programa . . . . . . . . . . . . . . . 48

Descripción de cada sesión. . . . . . . . . . . . . . . . . . . . 49

Evangelismo de la amistad . . . . . . . . . . . . . . . 49

Base para el evangelismo de la amistad . . . . . . . . 50

Importancia de la amabilidad . . . . . . . . . . . . . 51

Preparación espiritual para el evangelismo de la amistad . . . . . 54

Formas prácticas para la evangelización por la amistad . . . . . . 54

Modalidades de las presentaciones . . . . . . . . . . . . 56

Un solo día . . . . . . . . . . . . . . . . . 56

Fin de semana completo . . . . . . . . . . . . . . 57

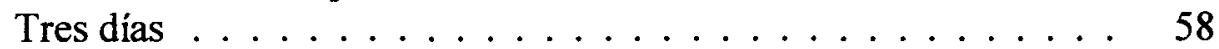

Tres sábados de tarde . . . . . . . . . . . . . . . . 59

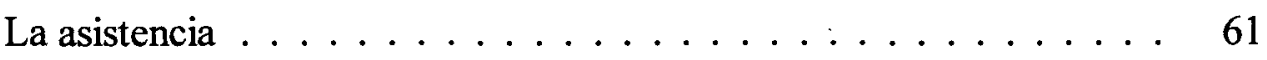

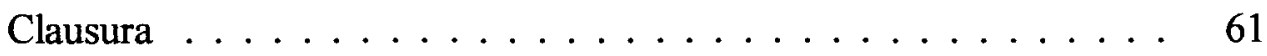

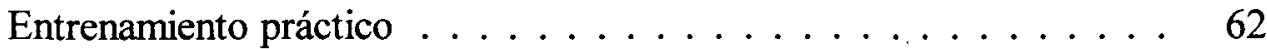

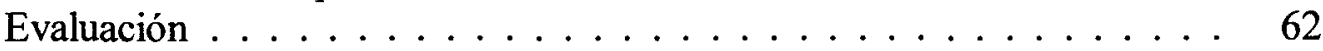

Evaluación antes de iniciar . . . . . . . . . . 63

Evaluación del aprovechamiento . . . . . . . . . . . 64

Evaluación del programa . . . . . . . . . . . . . . . 64

V. RESUMEN, CONCLUSIONES Y RECOMENDACIONES. . . . . . . . . 66

Resumen ...................... 66

Conclusiones . . . . . . . . . . . . . . . . 68

Recomendaciones . . . . . . . . . . . . . . . . 69

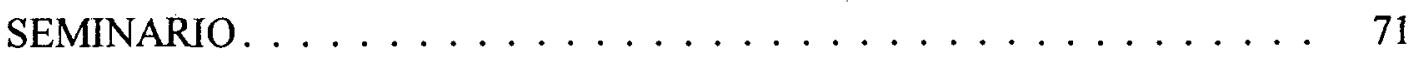

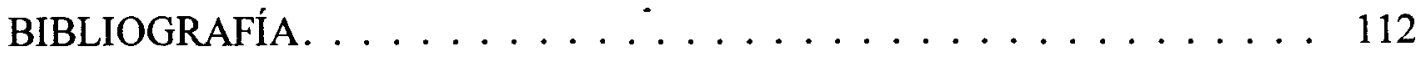

CURRÍCULUM VÍTAE. . . . . . . . . . . . . . . . . . . 118 


\section{CAPÍTULO I}

\section{INTRODUCCIÓN}

Uno de los factores fundamentales para el desarrollo de las buenas relaciones humanas es la amabilidad y la amistad hacia nuestros semejantes. El sentido de identidad personal y la aceptación del grupo permiten, tanto a propios como a extraños, sentirse bien consigo mismos y con los demás.

En el cumplimiento de la predicación del evangelio, es evidente la importancia y la necesidad de estos factores que en más de una ocasión permiten el rechazo o la aceptación de la verdad que la iglesia proclama.

El presente estudio tiene como finalidad mostrar la importancia del evangelismo de la amistad con base en la amabilidad como un medio de evangelización en la Iglesia Adventista del Séptimo Día. Para lograrlo, analiza la amabilidad en la Biblia, en los Escritos de Elena G. de White, y en las obras de otros autores que escriben sobre el tema.

\section{Propósito del proyecto}

El propósito de esta tesis es hacer un estudio del evangelismo de la amistad y preparar un seminario para instruir y enseñar a los miembros y dirigentes de la iglesia para que muestren en su trato amabilidad y amor cristiano con los visitantes y entre ellos mismos. 


\section{Justificación del proyecto}

La opinión de las iglesias evangélicas es que los miembros de la Iglesia Adventista son apáticos e indiferentes por la manera como se trata a los visitantes y entre los mismos miembros. Siendo que a las personas les gusta regresar o convivir donde se les trata bien es necesario instruir a la iglesia en la importancia de la amabilidad y en las buenas relaciones humanas.

Además, como la amistad cristiana es un medio para la predicación del evangelio, se requiere que los miembros sean amables y amistosos en su trato con todas las personas.

También la iglesia crece continuamente en feligresía, recibiendo a nuevos miembros. Debe, por lo tanto, estar preparada no sólo para recibirlos, sino también para retenerlos.

\section{Limitaciones del proyecto}

Este proyecto está limitado a realizar un estudio teórico del evangelismo de la amistad con base en la amabilidad y la preparación de un seminario para instruir y enseñar a los miembros y dirigentes de la iglesia para ofrecer un trato amable con todo tipo de personas que visitan la iglesia, y entre ellos mismos.

\section{Descripción del proyecto}

Este proyecto está organizado en cinco capítulos. Capítulo 1, la introducción, incluye propósito del estudio, la justificación del proyecto y las limitaciones del proyecto. El capítulo 2 es un estudio de la amabilidad basado en la Biblia, Antiguo y Nuevo Testamento, en los escritos de Elena G. de White y según otros autores. El capítulo 3 describe el significado de la frase "evangelismo de la amistad," su origen, la preparación 
indispensable para realizarlo y maneras prácticas para predicar el evangelio por medio de la amistad. El capítulo 4 es el desarrollo del seminario que incluye preparación, presentación y evaluación. El capítulo 5 contiene el resumen, conclusiones y recomendaciones. El apéndice muestra los visuales del seminario. La bibliografia consultada cierra la investigación. 


\section{CAPÍTULO II}

\section{FUNDAMENTOS TEÓRICOS DE LA AMABILIDAD}

La amabilidad en las relaciones humanas es importante, dado que la sociedad está formada de personas vivientes que razonan y que tienen necesidades. Ser amable significa ser sociable, atento, bondadoso, cordial y cortés. ${ }^{1}$ El adverbio "amablemente" describe el trato correcto, con altura y educación. El adjetivo "amable" caracteriza a la persona digna de ser amada. ${ }^{2}$

La amabilidad es un código de conducta que se manifiesta espontáneamente en palabras y actitudes hacia nuestros semejantes. Es un lenguaje particular que facilita las relaciones sociales y personales de la sociedad. ${ }^{3}$

Más que una actitud, la amabilidad es una cualidad humana a menudo coloreada por la experiencia y la educación. Esta cualidad se manifiesta en el trato cordial, en el uso de las palabras adecuadas, en la manera como se trata a las personas con las que se sociabiliza, y en el concepto que se tenga de los demás.

Este capítulo analiza la amabilidad en la Biblia, en los escritos de Elena G. de

\footnotetext{
${ }^{\mathrm{I}}$ Martín Alonso, Diccionario de sinónimos explicados (Madrid: Edaf, 1984), 45.

${ }^{2}$ Diccionario enciclopédico Quillet (México, D. F.: Cumbres, 1988), ver "amable".

${ }^{3}$ Anne-Marie de Vilaine, Sin temor a equivocarse (México, D. F.: Selecciones del Readers Digest, 1978), 42.
} 
White, y en las obras de varios autores que escriben sobre el tema.

\section{La amabilidad en la Biblia}

El significado dado en la Biblia a la palabra amabilidad es claro y profundo. Además, la Biblia presenta señalados ejemplos de personas que ejercieron verdadera amabilidad en el trato con sus semejantes. También contiene principios fundamentales que conducen a una conducta dispuesta a tratar bien a los demás.

\section{Antiguo Testamento}

El concepto usado en el Antiguo Testamento para referirse a la amabilidad está íntimamente relacionado con el carácter de Dios y la manifestación de sus atributos, en el trato con los seres humanos.

\section{Significado}

En el idioma hebreo el vocablo usado es jésed, traducido como bondad, amabilidad o gracia. El término aparece 245 veces en el Antiguo Testamento. Jésed no designa una amabilidad espontánea, sino un comportamiento que se deriva de una relación determinada por leyes y obligaciones. Sin embargo, cuando se refiere a la bondad de Dios en relación con sus promesas, recibe el sentido de amabilidad espontánea. ${ }^{1}$

Bíblicamente jésed designa la bondad en un sentido concreto. Incluye al que ofrece amabilidad como también al que la recibe; esto se manifiesta en las relaciones humanas. Pero cuando la bondad proviene de Dios, es simplemente la manifestación de

${ }^{1}$ Ernst Jenni, Diccionario teológico manual del Antiguo Testamento (Madrid: Cristiandad, 1978), ver "bondad". 
sus atributos. ${ }^{1}$

Además, la palabra tob y sus derivados se refieren a lo que posee cualidades deseables o excelencia de carácter. ${ }^{2}$ Un ejemplo bíblico de esta aplicación se encuentra en Neh. 9:25, 35, y Sal. $27: 13$. $^{3}$ Cuando el Señor le muestra a Moisés su gloria y le describe su carácter (Ex. 33:19, DHH) parece abarcar todas las virtudes de Dios, especialmente su bondad y su amabilidad. ${ }^{4}$ Se puede decir que el término significa buena voluntad que se manifiesta al realizar actos de bondad o amabilidad a favor de otros. ${ }^{5}$

La amabilidad que proviene de Dios se convierte en la disponibilidad de la persona que se olvida de sí misma para atender a los demás. En el Antiguo Testamento este principio de bondad se manifiesta de parte de Dios desde la misma creación del hombre. Dios mostró bondad o amabilidad con el hombre al crear una compañera para él.

"Y dijo Dios: No es bueno que el hombre esté solo; le haré ayuda idónea para él" (Gn. $2: 18)$

\section{Ejemplos bíblicos de amabilidad}

El relato del Antiguo Testamento presenta muchas historias donde se muestra la práctica de la amabilidad. Por ejemplo, en la historia de José y sus hermanos se presenta

'Jean-Jacques Von Allmen, Vocabulario bíblico (Madrid: Morora, 1968), 30.

${ }^{2}$ Siegfried H. Horn, Diccionario biblico adventista (Buenos Aires: Casa Editora Sudamericana, 1995), ver "bondad".

${ }^{3}$ Todas las referencias bíblicas se han tomado de la Versión Reina-Valera 1960.

${ }^{4}$ Horn, ver "bondad".

${ }^{5}$ Diccionario de la lengua española (Madrid: Espasa-Calpe, 1992), ver "amabilidad". 
una actitud altamente amable. ${ }^{1}$ "Y les respondió José: No temáis, ¿acaso estoy yo en lugar de Dios? . . A Ahora, pues, no tengáis miedo, y yo os sustentaré a vosotros y a vuestros hijos y les habló al corazón" (Gn. 50:19,21).

Moisés demostró amabilidad cuando intervino para defender a las hijas del sacerdote de Madián. "Mas los pastores vinieron y las echaron de alli; entonces Moisés se levantó las defendió, y dio de beber a sus ovejas" (Ex. 2:17).

El rey David fue objeto de un acto amable de parte de Abigail, esposa de Nabal. David subía con sus cuatrocientos guerreros, con espadas en las manos para destruir a Nabal porque había ofendido con palabras a los diez mensajeros que David había enviado para saludarlo y pedir provisiones. Abigail se enteró del problema y salió al encuentro de David usando palabras amables. Este acto de amabilidad cambió el curso de toda la historia de la nación ${ }^{2}$ (1 S. 25:12-35).

Otro incidente que muestra un acto amable, es el trato que le da David a Mefiboset. “El rey le dijo: ¿No ha quedado nadie de la casa de Saúl, a quien haga yo misericordia de Dios? Y Siba respondió al rey: Aun ha quedado un hijo de Jonatán, lisiado de los pies. . . Y vino Mefi-boset. . . Le dijo David: No tengas temor porque yo a la verdad haré contigo misericordia" (2 S. 9:3-7). El relato de David y Mefi-boset demuestra que no sólo es importante usar palabras amables sino que se requiere manifestar lo que realmente hay en el corazón. La respuesta amable no sólo debe ser de

\footnotetext{
${ }^{1}$ G. Charles Aalder The Book of Genesis (Grand Rapids: Zondervan, 1981), 296.

${ }^{2}$ Howard, F. Vos, 1, 2 Samuel, Bible Study Comentary (Grand Rapids: Zondervan, 1983), 85.
} 
forma, sino debe nacer del corazón. ${ }^{1}$

A continuación se presentan algunos principios bíblicos que muestran la importancia de saber relacionarnos con los demás de una manera amable.

\section{Principios bíblicos de la amabilidad}

La experiencia de Salomón, al tratar con mucha gente en su posición como rey, lo llevo a expresar con toda autoridad lo siguiente: "La blanda respuesta quita la ira, mas la palabra áspera hace subir el furor" (Pr. 15:1). Esta premisa del sabio nos muestra las consecuencias que pueden experimentarse en la vida social, cuando no se hace uso de la amabilidad en el trato con otros. El mismo rey Salomón, en el libro de los Proverbios, presenta algunos principios básicos y necesarios que nos permiten expresar y practicar la amabilidad en nuestras relaciones con nuestros semejantes.

"Panal de miel son los dichos suaves; suavidad al alma y medicina para los huesos" (Pr. 16:24).

"El que ama la limpieza de corazón, por la gracia de sus labios tendrá la amistad del rey" (Pr. 22:11).

"Los labios justos son el contentamiento de los reyes, y éstos aman al que habla lo recto" (Pr. 16:13).

"Besados serán los labios del que responde palabras rectas" (Pr. 24:26).

"Manzana de oro con figuras de plata es la palabras dicha como conviene" (Pr. 25:11).

"Los labios del justo apacientan a muchos, mas los necios mueren por falta de

${ }^{1}$ Alejandro Bullón, A solas con Jesús (Buenos Aires: Casa Editora Sudamericana, 1998), 184. 
entendimiento" (Pr. 10:21).

"La lengua apacible es árbol de vida; mas la perversidad de ella es quebrantamiento de espíritu" (Pr. 15:4).

Sería maravilloso decir siempre lo correcto, evitar las críticas y las palabras airadas. Debemos encomiar y alentar a otros y seguir los consejos de Salomón en cuanto a nuestra manera de hablar y de tratar al prójimo. ${ }^{1}$

\section{Origen de la amabilidad}

A lo largo de los libros del Antiguo Testamento, se manifiesta una constante actitud de ayuda y misericordia de parte de Dios, como formas de su bondad o amabilidad hacia su pueblo. ${ }^{2}$ Esto nos demuestra que el origen de toda bondad o amabilidad es Dios. Esta manifestación de su bondad se revela en forma especial en una serie de hechos históricos donde se muestra la intervención de Dios en favor de sus hijos.

Uno de esos hechos es la salida del pueblo de Israel de Egipto, en el cual se manifestó la bondad de Dios de manera clara (Ex. 12:37-51). La forma maravillosa como Dios abrió el Jordán revela otro acto bondadoso de su carácter (Ex. 14:15-30). Moisés define a Dios, como un Dios bondadoso y lleno de misericordia (Ex. 4:31). La bondad o amabilidad se refiere en toda la Biblia de manera principal a Dios quien es el único esencialmente bueno. ${ }^{3}$

La bondad como motivo de alabanza es un tema frecuente en los salmos donde la 1991), 85 .

${ }^{1}$ Russell Holt, Sabiduría para vivir (Miami: Casa Publicadora Interamericana,

${ }^{2}$ Leo Van Dolson, El Dios que habla y muestra (Buenos Aires: Casa Editora Sudamericana, 1998), 22.

${ }^{3}$ Enciclopedia de la Biblia (Barcelona: Garriga, 1963), ver "bondad". 
expresión, "alabad a Dios porque es bueno", sirve como introducción a varios de ellos, (Sal. 106:1, 107:1, 136:1). “La dimensión de la bondad de Dios no tiene límites prácticamente, ya que ofrece para todos y para todas sus obras".

De esta manera queda evidente que el origen de la genuina bondad, amabilidad y el buen trato hacia los seres humanos, sólo encuentra su correcta aplicación en Dios como el único perfecto.

\section{Nuevo Testamento}

De la manera como en el Antiguo Testamento se hace referencia al concepto de bondad o amabilidad, también en el Nuevo Testamento usan varias palabras para amabilidad, en el sentido de expresar un trato amable hacia los demás.

\section{Significado}

El término griego epieikēs, de epi, "hacia", y eikos, que se usa para denotar "placentero", "justo", "moderado", "paciente", además expresa aquella consideración que examina de forma "humana y razonable los hechos de un asunto".

Epieikès se traduce como amable en 1 Ti. 3:3: "No dado al vino, no pendenciero, no codicioso de ganancias deshonestas, sino amable, apacible, no avaro". En Tit. 3:2, se hace mención de este vocablo como contraste de ser pendenciero. "Que a nadie difamen, que no sean pendencieros, sino amables, mostrando toda mansedumbre para con todos los

${ }^{1}$ Ibíd.

${ }^{2}$ W. E. Vine, Diccionario expositivo de palabras del Nuevo Testamento (Terrassa, Barcelona: CLIE, 1984), 86. 
hombres". 15

En Stg. 3:17 se hace referencia a este término en relación a la sabiduría: "Pero la sabiduría que es de lo alto es primeramente pura, después pacifica, amable, benigna, llena de misericordia y de buenos frutos, sin incertidumbre ni hipocresía". En Fil. 4:5 se traduce como gentileza: "Vuestra gentileza sea conocida de todos los hombres. El Señor está cerca". ${ }^{16}$

Otra palabra griega que se utiliza para amable es profilēs, de pros, "hacia", y fileõ, "amar", cuyo significado es "placentero", "agradable", "amable". Esta referencia se encuentra en el siguiente pensamiento: "Por lo demás hermanos, todo lo que es verdadero, todo lo honesto, todo lo justo, todo lo puro, todo lo amable, todo lo que es de buen nombre ; si hay virtud alguna, si algo digno de alabanza, en esto pensad" (Fil. 4:8). ${ }^{17}$

El apóstol Pablo usa la palabra êpios para hablar de su propia conducta y la de sus compañeros de misión en relación al trato hacia los nuevos conversos en Tesalónica, "Antes fuimos tiernos entre vosotros, como la nodriza que cuida con ternura a sus propios hijos" (1 Ts. 2:7). También es usada la palabra para mostrar la conducta requerida de un siervo del Señor: "Porque el siervo del Señor no debe ser contencioso, sino amable para con todos, apto para enseñar, sufrido" (2 Ti. 2:24).

También otra palabra que es usada para hablar de bondad, de ser bueno y de hacer el bien, es el vocablo agathosune ${ }^{18}$ que describe a toda aquella persona que ha sido

${ }^{15}$ Everett F. Harrison, ed. Diccionario de teología biblica Moody (Chicago: Moody, 1971), 424.

${ }^{16}$ Johannes B. Bauer, Diccionario de teología bíblica (Barcelona: Herder, 1967), 149.

\footnotetext{
${ }^{17}$ Vine, 86.

${ }^{18}$ Ibíd., 201.
} 
regenerada y muestra una actitud moralmente buena. En Ro. 15:14, Pablo hace referencia a esta actitud de tratarse con bondad o amabilidad unos con otros.

\section{La amabilidad en los escritos de Pablo}

De los escritores del Nuevo Testamento, Pablo es uno de los que más escribió acerca de la amabilidad. En la mayoría de sus cartas, se puede encontrar referencias muy marcadas en relación a la manera de tratar a los demás. Por ejemplo, al escribir a la iglesia de Roma acerca de los deberes cristianos, enfatiza la importancia de ser un elemento de paz en las relaciones con el mundo. "Si es posible, en cuanto dependa de vosotros, estad en paz con todos los hombres" (Ro. 12:18).

El mismo apóstol, refiriéndose a la nueva vida en Cristo, comenta: "Ninguna palabra corrompida salga de vuestra boca, sino la que sea buena para la necesaria edificación, a fin de dar gracia a los oyentes" (Ef. 4:29). Además; agrega en la epístola a los Colosenses: "Sea vuestra palabra siempre con gracia, sazonada con sal, para que sepáis como debéis responder a cada uno" (Col. 4:6). El énfasis del apóstol es mostrar que es importante mantener buenas relaciones con la gente; es decir, debemos manifestar amabilidad en nuestros actos, no importa si es con los miembros de la misma iglesia o con personas que no pertenecen a la iglesia.

Otro de los escritores del Nuevo Testamento que enfatiza la importancia de la cortesía o amabilidad, es el apóstol Pedro. ${ }^{19}$ Refiriéndose a los deberes entre los esposos, dice: "Finalmente, sed todos de un mismo sentir, compasivo, amándoos fraternalmente, misericordiosos, amigables" (1 P. 3:8). Aquí el apóstol hace una invitación a la bondad

${ }^{19} \mathrm{John}$ H. Elliott, I-II Peter, Augsburg Commentary en the New Testament (Minneapolis: Augsburg, 1982), 92. 
en las relaciones humanas y al buen trato entre los seres humanos.

Por esta razón los escritos del Nuevo Testamento, contienen los principios para cultivar la virtud de la cortesía y la amabilidad para vivir en armonía unos con otros.

\section{La amabilidad en los escritos de Elena G. de White}

En sus escritos la autora Elena G. de White ${ }^{1}$ hace referencias bien marcadas a la importancia del buen trato entre los seres humanos. Además presenta principios guiadores que, puestos en práctica, aseguran el éxito en el arte de llevarse bien con los demás. También muestra que la amabilidad es un medio evangelizador muy importante.

\section{Importancia en las relaciones humanas}

White asevera que la amabilidad es uno de los requisitos indispensables para las buenas relaciones humanas. El principio de ser "sinceramente amables unos con otros" llega a ser el fundamento necesario para vivir en sociedad. ${ }^{2}$

Presenta la amabilidad como una de las gracias del Espíritu, que tiene poder para suavizar la naturaleza del hombre en su trato con los demás. ${ }^{3}$ Afirma que en nuestras relaciones interpersonales la ausencia de amabilidad hace que el trato sea duro y áspero. El cultivo de una cortesía uniforme, la voluntad de tratar a otros como desearíamos ser tratados nosotros, y la disposición a ser amables, eliminaría la mitad de las dificultades de

${ }^{1}$ Elena G. de White (1827-1915), "cofundadora de la iglesia Adventista del Séptimo Día, escritora y consejera, poseyó lo que la iglesia Adventista ha aceptado como el don de profecía". Sevenday-day Adventist Encyclopedia (1996), ver "White, Ellen Gould (Harmon)".

${ }^{2}$ Elena G. de White, Felicidad y armonia en el hogar (Mountain View, CA: Publicaciones Interamericanas, 1975), 161.

${ }^{3}$ Elena G. de White, Obreros evangélicos (Mountain View, CA: Publicaciones Interamericanas, 1974), 127. 
la vida.

El actuar de acuerdo a la verdadera amabilidad, cuando proviene del corazón donde vive Cristo, se manifiesta en una conducta que conquista el corazón de los demás.

Hablando en relación a la formación del carácter, comenta que cuando el ser humano es educado desde la infancia en los principios correctos de la verdadera amabilidad, tendrá la posibilidad de usarlos toda la vida. ${ }^{2}$

En todo momento deben observarse modales correctos; dondequiera que no haya principios en juego, la consideración hacia los demás inducirá a adaptarse a costumbres aceptadas. La verdadera cortesía no requiere el sacrificio de los principios al convencionalismo. No conoce castas. Enseña el respeto propio, el respeto a la dignidad del ser humano como persona. ${ }^{3}$

\section{Importancia en la religión}

En lo que concierne a la religión como parte de la vida, esta autora dice: "La religión de Jesús ablanda cuanto haya de duro y brusco en el genio, suaviza lo tosco y violento de los modales. Hace amable las palabras y atrayente el porte". ${ }^{4}$ Como resultado de una religión práctica, la amabilidad nos permite ofrecer un trato imparcial en nuestras relaciones personales, sin clasificar a las personas en clases o rango, rompiendo de esta manera el aislamiento social. Es por eso que la esencia de la verdadera cortesía es

${ }^{1}$ Elena G. de White, El ministerio de la bondad (Mountain View, CA: Publicaciones Interamericanas, 1977), 161.

${ }^{2}$ Elena G. de White, Reflejemos a Jesús (Buenos Aires: Casa Editora Sudamericana, 1985), 301.

${ }^{3}$ White, Felicidad y armonia en el hogar ${ }_{2} 163$.

${ }^{4}$ White, Reflejemos a Jesús, 22. 
la consideración hacia los demás. ${ }^{27}$

En una carta dirigida a un grupo de hermanos, comenta: "La influencia de Cristo en el corazón se percibirá en una amabilidad habitual, en un amor más que humano. La dulce paz del cielo estará en el alma y se revelará en los semblantes". ${ }^{28}$ En otra carta que ella misma dirigió a un administrador de la iglesia, hace referencia al ejemplo de Jesús en su relación con los seres humanos durante su ministerio, "Cristo siempre manifestó una amabilidad celestial en el trato con las almas humanas". ${ }^{29}$

Como una evidencia del crecimiento en la vida cristiana, los cristianos deben reflejar el lado alegre y amable de la religión. El lado brillante de la religión será revelado por todos aquellos que se consagren diariamente a Dios. ${ }^{30}$

De esta forma, la verdadera religión dará resultados que se verán en una personalidad alegre y de modales corteses y amables, no como consecuencia del aprendizaje de los principios de urbanidad, o la mera práctica de las reglas de etiquetas que el mundo utiliza, sino por la presencia del Espíritu de Cristo en el corazón ${ }^{31}$. Ésta es la evidencia que el mundo espera ver en los fieles servidores del Señor, y que le dan valor

${ }^{27}$ Elena G. de White, El evangelismo (Mountain View, CA.: Publicaciones Interamericanas, 1976), 462.

${ }^{28}$ Elena G. de White, Carta 6,14 de enero de 1899, dirigida a los hermanos reunidos en el congreso anual de Sunnyside, Cooranbong, Australia, Centro White, Universidad de Montemorelos, N. L., México.

${ }^{29}$ Elena G. de White, Carta 324, 3 de octubre de 1907, dirigida a un administrador, Centro White, Universidad de Montemorelos, N. L., México.

${ }^{30}$ Elena G. de White, La maravillosa gracia de Dios (Mountain View, CA.: Publicaciones Interamericanas, 1973), 184.

${ }^{31}$ Elena G. de White, Maranata: El Señor viene (Mountain View, CA.: Publicaciones Interamericanas, 1976), 235. 
al cristianismo práctico. ${ }^{1}$

Como se puede observar, Elena G. de White presenta de manera clara y precisa la importancia de la enseñanza y la práctica de la verdadera amabilidad, en el medio en que el ser humano se desarrolla. Es un factor determinante para establecer relaciones personales buenas y sinceras.

\section{Como medio de evangelismo}

Para Elena de G. White, la amabilidad no sólo es importante y necesaria para llevarse bien con la gente y establecer un ambiente agradable con los demás. Para ella, la amabilidad juega un papel determinante en el cumplimiento de la predicación del evangelio.

\section{Con palabras y actos amables}

El mundo que nos rodea se aísla cada vez más. Por eso hoy se necesita ver actos y hechos amables, que reflejen una vida consecuente con lo que se predica. ${ }^{2}$

Es necesario que en todo momento se observen modales correctos que nazcan de un corazón lleno de simpatía y amor a Cristo, manifestados por un interés abnegado por nuestros semejantes. $^{3}$

Todos los que han aceptado el llamado a trabajar en favor de las almas deben ser amables y corteses. La amabilidad constituye un poderoso elemento evangelizador

\footnotetext{
${ }^{1}$ Elena G. de White, La educación (Mountian View, CA.: Publicaciones Interamericanas, 1958), 235.

${ }^{2}$ Elena G. de White, Consejos sobre la obra de la escuela sabática (Buenos Aires: Casa Editora Sudamericana, 1954), 112.

${ }^{3}$ Elena G. de White, Servicio cristiano eficaz (Mountain View, CA. Publicaciones Interamericanas, 1977), 161.
} 
cuando es usada de manera sencilla y humilde. Al respecto, White certifica, "Si quisiéramos humillarnos ante Dios, ser amables, corteses y compasivos, se producirían cien conversiones a la verdad allí donde se produce una ahora". ${ }^{1}$ De esta manera la autora enfatiza la importancia de la relación que debe existir entre la religión y la conducta de los cristianos al tratar en sus diversas actividades, con todo tipo de personalidades.

En relación al efecto que tienen las palabras y los modales del cristiano comprometido con la predicación del evangelio, la autora afirma: "Son las palabras agradables y llenas de simpatía, la manifestación del amor desinteresado por las almas, lo que romperá las barreras del orgullo y del egoísmo y mostrará a los incrédulos que poseemos el amor de Cristo; y entonces la verdad se abrirá camino al corazón. ${ }^{2}$

Las palabras amables y gratas, dichas con sinceridad, tienen el poder de levantar el ánimo en la persona que las escucha y, además, despiertan el deseo de mejorar. Hay en ellas la fuerza motivadora necesaria que anima al individuo a esforzarse para hacer mejor las cosas. "Un cristiano bondadoso y cortés es el argumento más poderoso que se pueda presentar a favor del cristianismo". 3

Además, asevera, las palabras bondadosas son como rocío y suaves lluvias para el alma. Alude a la Escritura y comenta acerca de Cristo lo siguiente: la gracia fue derramada sobre sus labios, "para que supiese hablar palabras al cansado (Isa. 50:4)". 4

\footnotetext{
${ }^{1}$ White, El ministerio de la bondad, 127.

${ }^{2}$ White, El evangelismo, 462.

${ }^{3}$ White, Obreros evangélicos, 128.

${ }^{4}$ White, Reflejemos a Jesús, 22.
} 
Su conclusión es que la verdad debería ser presentada con tacto, suavidad y ternura de lo alto. Debería proceder de un corazón que ha sido ablandado y simpatiza con el pecador. ${ }^{1}$

\section{Con disposición al servicio amable}

El servicio en favor los demás es un principio divino. Servir fue el lema del ministerio de Cristo en este mundo (Mr. 10: 43-45). Cuando el cristiano está dispuesto a servir de manera alegre y amable, demuestra el espíritu de Cristo en su vida.

Refiriéndose a esta manera de ser, White comenta: "El espiritu de trabajo desinteresado por otros da al carácter profundidad, firmeza, y amabilidad parecida a la de Cristo; trae paz y felicidad al que lo posee". ${ }^{2}$

En relación a los métodos de evangelización, añade: "Mis hermanos y hermanas, visitad a los que viven cerca de vosotros, y por la simpatía y la bondad procurad alcanzar sus corazones. Aseguraos de trabajar de manera que quite el prejuicio en lugar de crearlo"3 $^{m}$

El servicio desinteresado en favor de nuestros parientes, amigos y vecinos, que no conocen la verdad, es altamente reconocido por el cielo. En este sentido, White nos informa: "Cuando el corazón simpatiza con los corazones cargados de desánimo y dolor, cuando la mano da a los necesitados, cuando se viste a los desnudos, y el extraño recibe la

\footnotetext{
${ }^{1}$ Elena G. de White, El otro poder (Buenos Aires: Casa Editora Sudamericana, 1996), 72.

${ }^{2}$ Elena G. de White, El camino a Cristo (Mountain View, CA.: Publicaciones Interamericanas, 1979), 80.

${ }^{3}$ Elena G. de White, Servicio cristiano eficaz (Mountain View,CA.: Publicaciones Interamericanas, 1973), 144.
} 
bienvenida, un asiento en la sala y un lugar en el corazón, los ángeles se acercan y en el cielo resuenan melodías como respuesta".

En referencia al método usado por Cristo, presenta la siguiente afirmación: "Sólo el método de Cristo permitirá éxito en alcanzar al pueblo. El Salvador se trataba con los hombres como alguien que deseaba su bien. Les mostraba simpatía, atendia sus necesidades y se ganaba su confianza. Entonces les decía: Seguidme". ${ }^{2}$ De esta manera podemos decir que el servicio amable y cordial es un medio poderoso para evangelizar.

\section{Con una amistad amable}

En la relación con sus discípulos, Jesús destacó la importancia de una amistad amable y sincera y enfatizó la manera como demostrarla (Jn. 15:15). Había un hogar que se deleitaba en visitar: la casa de Lázaro, María y Marta; porque en la atmósfera de fe y amor, su espíritu hallaba descanso. ${ }^{3}$ Los miembros de esta familia eran amigos de Jesús; White puntualiza que allí encontraba una sincera bienvenida y una amistad pura y santa. ${ }^{4}$

Esta relación de amistad sincera y amable de Jesús caracterizó todo su ministerio terrenal; no hacia distinción de personas. Aunque era judío, se relacionaba libremente con los samaritanos. Dormía bajo su techado, comía con ellos en su mesa, compartiendo los manjares preparados y servidos por sus manos, enseñaba en sus calles, y los trataba

${ }^{\mathrm{I}}$ Elena G. de White, Testimonies for the Church, 9 vols. (Mountain View, CA.: Pacific Press, 1948), 1:25.

${ }^{2}$ Elena G. de White, El ministerio de curación (Mountain View, CA. Publicaciones Interamericanas, 1975), 133.

${ }^{3}$ Elena G. de White, El Deseado de todas las gentes (Mountain View, CA.: Publicaciones Interamericanas, 1955), 482.

${ }^{4}$ Ibíd. 
con la mayor bondad y cortesía. ${ }^{1}$

Este ejemplo de Jesús nos demuestra que la amistad amable y sincera da una oportunidad para presentar el evangelio. White también menciona que al par que se ganaba sus corazones por su humana simpatía, su gracia divina les llevaba la salvación que los judíos rechazaban. ${ }^{2}$

Hablando de la importancia de las relaciones humanas, enfatiza que por medio del trato social se contraen relaciones y se forman amistades que unen los corazones y crean un ambiente de amor que agrada al cielo. ${ }^{3}$

En la predicación del evangelio, la cualidad de ser amistosos es un medio útil para que muchos puedan conocer a Jesús. Mediante las relaciones sociales el cristianismo se trasmite al mundo. Cada hombre y mujer que ha gustado el amor de Cristo, y ha recibido divina iluminación en su corazón, tiene la obligación ante Dios de iluminar el sendero de los que no conocen el camino mejor. ${ }^{4}$

La influencia social santificada por el Espíritu de Cristo, debe ser aprovechada para llevar almas al Salvador. "Debemos tener a Cristo en nosotros como fuente de agua que salte para vida eterna y que refresque a todos los que entran en contacto con nosotros."

A continuación se presenta la opinión de otros autores con respecto al tema de la

\footnotetext{
${ }^{1}$ White, Ministerio de curación, 15, 16.
}

${ }^{2}$ Ibíd.

${ }^{3}$ White, Testimonies for the Church, 1: 172.

${ }^{4}$ Elena G. de White, Manuscrito, 59, 1897, Centro White, Universidad de Montemorelos, N. L., México.

${ }^{5}$ White, Camino a Cristo, 125, 126. 
amabilidad.

\section{La amabilidad según otros autores}

El concepto de las relaciones humanas ha sido un tema discutido y estudiado por muchos autores del pasado y contemporáneos. El trato entre los seres humanos y el comportamiento de las diversas clases de la sociedad ha sido también un asunto de investigación.

Algunos autores que escriben acerca de este tema, y específicamente en relación a la amabilidad, el trato cordial y los buenos modales, mencionan que una conducta cortés y bondadosa esta sujetas a varios patrones de comportamiento. En esta sección se presenta la opinión de algunos autores al respecto.

\section{Sujeta a las circunstancias}

Para Alan C. Filley estas virtudes están sujetas a las circunstancias y a un conjunto de reglas de conducta propios para cada ocasión. Como humanos, vivimos dentro de una red de relaciones sociales, la mayor parte de la cuales parecen predecibles de una manera casi mecánica, pero a la vez son espontáneas en su funcionamiento y expresión. ${ }^{1}$

Juan Flores, en El libro de oro de la cortesía, señala que la amabilidad no siempre está inspirada por la bondad, equidad, complacencia o gratitud, sino que se reviste de apariencias y puede ser usada circunstancialmente. ${ }^{2}$ Es decir, la amabilidad o el ser amable dependen del medio donde se encuentre el individuo.

\footnotetext{
${ }^{1}$ Alan C. Filley, Solución de conflictos interpersonales (México, D. F.: Trillas, 1991), 11.

${ }^{2}$ Juan Flores, El libro de oro de la cortesía (Barcelona: Juan Pueyo, 1967), 5.
} 
B. F. Skinner, hablando de la conducta "operante", puntualiza que la mayoría de nuestros problemas implican conducta humana, y que no se pueden resolver recurriendo a la tecnología, porque el ser humano actúa en base a estímulos que recibe del medio ambiente. Por lo tanto, el ambiente puede modificar la conducta en el trato con las personas. ${ }^{1}$

\section{Código de conducta}

Para Pierre G. Weil el medio ambiente es un factor determinante para practicar la amabilidad, ya que la amabilidad, es ante todo un código de respeto que permite establecer relaciones entre seres humanos que viven en un grupo o una comunidad determinada. ${ }^{2}$ De esta manera ser amable dependerá más del ambiente que rodea al individuo que de los principios de urbanidad y buen gusto que intrínsecamente posea.

Para otros, como K. Keyes, la amabilidad no es el arte de adular con el propósito de conquistar la simpatía de otros. Es sentir y mostrar respeto por los demás. Es el proceso de interacción, donde los buenos modales nos permiten mantener relaciones agradables con otros. La amabilidad, es un código de conducta que permite interactuar en la sociedad facilitando un lenguaje particular que suaviza la convivencia en el medio. ${ }^{3}$

Al respecto, Paul Welter comenta lo siguiente: "En nuestra sociedad existen personas amables por formación o como resultado del aprendizaje. También hay un 1986), 23.

'B. F. Skinner, Más allá de la libertad y la dignidad (Barcelona: Martínez Roca,

${ }^{2}$ Pierre G. Weil, Relaciones humanas en el trabajo y la familia (Buenos Aires: Kapelusz, 1965), 21.

${ }^{3}$ Kenneth S. Keyes, Como desarrollar su habilidad mental (México, D. F.: Trillas, 1966), 149. 
número reducido de personas amables que siguen los dictados del corazón. Para ellos, los actos amables son el reflejo de la comprensión, del interés por los demás que nace del corazón sincero y anheloso de ser útil".

\section{Conjunto de deberes positivos}

Para Gregorio Fingermann, el uso de la amabilidad es muy importante en todas nuestras relaciones sociales, dado que tratamos con criaturas emotivas, erizadas de prejuicios e impulsadas por el orgullo y la vanidad. ${ }^{2}$ Según Filley, el mostrarse amable frente a un conflicto facilita las alternativas para la solución, ya que la amabilidad es el fruto de una naturaleza noble, de la decencia y de un espiritu elevado. ${ }^{3}$

El escritor Henri Pradel define la amabilidad como las cosas que debemos hacer y debemos decir de la manera apropiada dada la circunstancia. Agrega además, que es un conjunto de deberes positivos que motivan a la conscientización del buen trato. ${ }^{4}$

La mayoría de los autores referidos mencionan que el uso de la amabilidad y el buen trato hacia los demás están sujetos a las circunstancias del medio ambiente que rodea a las personas. Sin embargo, la amabilidad es una virtud útil, que debe ser usada en cualquier etapa de la vida. Bien orientada produce buenos resultados, dignifica a la persona que la ofrece y ennoblece a la persona que la recibe. ${ }^{5}$ En su sentido práctico la

\footnotetext{
${ }^{1}$ Paul Welter, Cuando tu amigo te necesita (Miami: Unilit, 1990), 9.

${ }^{2}$ Gregorio Fingermann, Relaciones Humanas (México, D. F.: Ateneo, 1982), 2.

${ }^{3}$ Filley, 72 .

${ }^{4}$ Henri Pradel, Educación de la cortesia (México, D. F: Ediciones Paulinas, 1959), 119.

${ }^{5}$ Margery Wilson, The Pocket Book Etiquette (New York: Pocket Book, 1941), 115.
} 
amabilidad es un estilo de vida que fortalece la convivencia entre quienes la practican independientemente del medio ambiente que rodee a la persona. El estudio y la aplicación de la amabilidad deben ser la preocupación de los educadores, de los padres y de cada persona capaz de vivir en sociedad. ${ }^{1}$

La bondad corre el peligro de volverse una virtud extinguida, por las condiciones de la vida moderna. La vida agitada y de prisa que nos rodea tiende a hacer a los seres humanos insensibles respecto al trato hacia los demás ${ }^{2}$

Por el desarrollo acelerado del mundo, se requiere que los seres humanos muestren un trato especial en sus relaciones personales. El ser humano es sociable por naturaleza. Por esto, se necesita satisfacer las necesidades fisicas, emocionales y espirituales de toda persona. ${ }^{3}$ Por lo tanto, la amabilidad debe ser practicada diariamente como un compromiso personal.

Los principios ya mencionados nos permiten afirmar que de "la manera como nos relacionamos con nuestras palabras, nos relacionamos también con nuestros corazones. Es decir, lo que decimos y hacemos expresa lo que está en nuestra mente. Es por eso que no debemos olvidar que la habilidad de tratar con los demás lleva consigo una íntima comprensión de la naturaleza humana y una genuina preocupación por las necesidades y sentimientos ajenos." ${ }^{4}$

${ }^{1}$ Pradel, 119.

${ }^{2}$ George, E. Rice, Una esperanza viva (Buenos Aires: Casa Editora Sudamericana, 1992), 65.

${ }^{3}$ David N. Griffiths, Implementando la calidad (México, D. F.: Panorama, 1992), 21.

${ }^{4}$ Cyril J. Barber, Nehemias: Dinámica de un líder (Miami: Vida, 1976),170. 
Cuando se actúa conscientemente, basado en estos principios básicos, queda demostrado que el trato amable y cortés permite crear un ambiente agradable. " $" \mathrm{La}$ bondad, la mansedumbre y la amabilidad desarmarán al más furioso, excepto cuando éste ha perdido el juicio". ${ }^{2}$

Las palabras que hablamos, buenas o malas, parecen tener vida en sí mismas. Influyen sobre otros en formas inimaginables. Una palabra, dicha con amabilidad sincera, puede echar raíces en la mente de otro y cambiar su vida para siempre. ${ }^{3}$

De esta manera las fuentes consultadas muestran la importancia de conocer y practicar los principios y normas de la amabilidad. Esto permitirá que exista una mejor convivencia y un compañerismo saludable entre los seres humanos.

${ }^{1}$ George Barna, User Friendly Churches (Ventura, CA.: Regal, 1991), 42.

${ }^{2}$ Adam Clarke, Comentario de la Santa Biblia (Kansas City, MO: Casa Nazarena, 1980), 3:138.

${ }^{3}$ Holt, 87. 


\section{CAPÍTULO III}

\section{EL EVANGELISMO DE LA AMISTAD}

Como fue mencionado en el capítulo anterior, la amabilidad es un factor importante en las relaciones humanas. Además se hizo referencia a la amabilidad sincera como la base para establecer buenas amistades.

El propósito de este capítulo es demostrar que la amistad como resultado de la amabilidad es un medio útil en la predicación del evangelio. También se definirá que es "evangelismo de la amistad". Se mostrarán algunos ejemplos bíblicos y algunas maneras prácticas para realizar esta forma de evangelización.

\section{Definición}

El evangelismo de la amistad es la manera práctica de compartir la ayuda con las personas que nos rodean y hacerles saber que Dios las ama y que hay esperanza para ellas. ${ }^{1}$ Es el proceso por el cual se permite un tipo de relación positiva y favorable que facilita establecer el fundamento para que exista una amistad verdadera, que prepara el corazón de las personas para presentar el evangelio. ${ }^{2}$

Es una forma natural de proceder, aprovechando todas las oportunidades que se

\footnotetext{
${ }^{1}$ Monte Sahlin, Friendship Evangelism (Siloam Springs: Concerned Comunications, 1990), 6.

${ }^{2}$ Rosalind Rinker y Harry C. Griffith, Compartiendo el amor de Dios (Terrasa: Barcelona: CLIE, 1976), 79.
} 
abren de por sí para hablar en términos amables y cristianos, que dejen la puerta abierta para establecer una amistad. Es un método mediante el cual las personas se relacionan informalmente mediante asociaciones voluntarias, contactos profesionales, lazos familiares o raciales, y otras conexiones, con el propósito de evangelizar. ${ }^{1}$

Son muchos los que necesitan el ministerio de corazones cristianos amantes en todas partes. En la familia misma, en el vecindario, en el pueblo en que vivimos, muchos están esperando que se les hable personalmente a través del evangelismo de la amistad. ${ }^{2}$

De acuerdo a estos conceptos se puede decir que evangelismo de la amistad, es el método de conducir a una persona a Cristo cuando lo hacemos nuestro amigo primero, y sólo entonces compartimos el evangelio con ella.

\section{Base para el método del evangelismo de la amistad}

El ser humano posee sentimientos y virtudes, como también necesidades, que debe satisfacer en todas las etapas de la vida. La expresión total de la persona necesita de un clima de seguridad, de comprensión, de paciencia y afecto que sólo la amistad en un alto grado puede aportar. ${ }^{3}$

Se puede decir que la idea del evangelismo de la amistad viene de algunos textos de la Biblia como estos: "Vino el Hijo del Hombre, que come y bebe, y decís: Este es un hombre comilón y bebedor, amigo de publicanos y de pecadores" (Lc. 7: 34). "Ya no os llamaré siervos, porque el siervo no sabe lo que hace su señor; pero yo os he llamado

\footnotetext{
${ }^{1}$ Ray Bakke y Jim Hart, The Urban Christian (Downers Grove: InterVarsity, 1987), 14.

${ }^{2}$ White, El Deseado de todas las gentes, 155.

${ }^{3}$ Vidal Ayala, Pastoral y evangelización de jóvenes (Madrid: ICCE, 1977), 72.
} 
amigos, porque todas las cosas que oi de mi Padre, os las he dado a conocer" (Jn. 15:15).

No se puede definir la amistad con exactitud científica, porque se trata de los valores que posee el ser humano, que se manifiestan en el interés de pensar en el bien de los demás, antes que en el nuestro. ${ }^{1}$ Este aspecto importante de la amistad fue utilizado por Jesús durante su ministerio en favor de los seres humanos. White comenta al respecto: "Sólo el método de Cristo será el que dará éxito para llegarse a la gente. El Salvador trataba con los hombres como quien deseaba hacerles un bien. Les mostraba simpatía, atendía sus necesidades y ganaba su confianza. Entonces les decía: Seguidme".

Según afirma Monte Sahlin, la evangelización será más fácil dentro de los lazos de amistad existentes, debido que ya se tiene credibilidad con los amigos y miembros de la familia que son los más probables de tomar el evangelio seriamente. ${ }^{3}$ Este método permite realizar lo que se le llama "trabajo en cadena". Las cadenas son las posibilidades de relación que se pueden tener, las personas con que se puede hablar cada día. ${ }^{4}$

En la vida práctica, el evangelismo de la amistad comienza con la relación personal con Cristo y el sentir amor por las almas que carecen del mensaje del evangelio. ${ }^{5}$

Es posible el evangelismo de la amistad al acercarse a las personas y conquistarles la confianza y ofrecerles amistad sintiendo interés por su salvación. La

\footnotetext{
${ }^{1}$ Naomi Rhode, El don de la amistad (México, D. F.: Selector, 1991), 73.

${ }^{2}$ White, Ministerio de curación, 102.

${ }^{3}$ Sahlin, 2.

${ }^{4}$ Ibíd.

${ }^{5}$ White, El camino a Cristo, 80.
} 
evangelización por la amistad, al igual que los testimonios personales, surgen de una vida consciente, lo que se haga servirá para la edificación de relaciones que abrirán las puertas con el propósito de ganar acceso al corazón con el fin de conducir personas al evangelio. Sirve como puente entre los senderos primarios de entrada al evangelio y los niveles más profundos de la doctrina. ${ }^{1}$

\section{Ejemplos bíblicos}

La comunicación del evangelio por la amistad a parientes y amigos está fundamentada en la Biblia. Hay muchos ejemplos bíblicos que muestran cómo, una vez que el evangelio fue introducido por un extraño, el crecimiento de la iglesia ocurría mediante nuevos conversos o por medio de una red de relaciones personales.

Lidia, la mujer de negocios de Filipos, fue bautizada con su familia (Hch. 16:14, 15). El carcelero de Filipos "se bautizó con todos los suyos" la noche misma de su conversión "y se regocijó con toda su casa por haber creído a Dios (16:30-34). Como preparación para la llegada de Pedro, Cornelio había "convocado a sus parientes y amigos más íntimos" (10:24).

Al seleccionar a sus discípulos el Señor utilizó el evangelismo de la amistad. El llamó a los dos primeros; uno de ellos fue Andrés. Éste presentó a su hermano Simón a Jesús (Jn. 1:40-42). Al día siguiente Jesús llamó también a Felipe. "Y Felipe era de Betsaida, la ciudad de Andrés y Pedro" (v. 44). Es posible que Andrés y Pedro hayan invitado a Felipe para que se encontrara con Jesús. Más tarde, Felipe puso en contacto a su amigo Natanael con Jesús (vv. 45-51). En el ministerio de Jesús se encuentra un

${ }^{1}$ Carlos Martín, Como trastornar al mundo (Buenos Aires: Casa Editora Sudamericana, 2000), 60 
ejemplo práctico de evangelismo de la amistad. "Nuestro Salvador iba de casa en casa, sanando a los enfermos, consolando a los que lloraban, calmando a los afligidos, hablando palabras de paz a los desconsolado. Con inagotable ternura y amabilidad, encaraba toda forma de desgracia y aflicción humana". 1

Esta actitud de Cristo muestra que una manera de realizar el evangelismo de la amistad es interesarse en el bienestar de los demás, atendiendo sus necesidades. Esto lo demostró desde el mismo inicio de su ministerio, al manifestar su poder en una reunión familiar, celebrada en una pequeña aldea de Galilea, para aumentar el placer de una fiesta de bodas. Así reveló su simpatía y su amistad por la humanidad y el deseo de contribuir a su felicidad (Jn. 2:1-10).

Otros ejemplos de este tipo de evangelización, son los casos registrados en Hch.18:1-4, 7, 8, 24-27, que muestran la influencia de amigos sobre otros amigos para la aceptación del evangelio.

v. 1-3. Pablo estableció relaciones de amistad con Aquila y Priscila y trabajó con ellos.

v. 7, 8. Pablo estableció una iglesia en el hogar de su amigo Justo. Aquella iglesia de hogar atrajo a Crispo, el jefe de la sinagoga, y a muchos otros.

v. 19, 24-27. Pablo dejó a Priscila y Aquila en Efeso. Ellos hicieron amistad con Apolos, lo llevaron a su hogar y le enseñaron acerca de Cristo. Apolos conmovió a Corinto y compartió las buenas nuevas que Aquila y Priscila le habían dado.

Más tarde, Priscila y Aquila se trasladaron a Roma y establecieron una iglesia amigable en su propio domicilio (Ro. 16:3-5). De esta manera es evidente que en el

\footnotetext{
${ }^{1}$ White, Servicio cristiano eficaz, 143.
} 
proceso por el cual el conocimiento de Cristo se esparció desde Jerusalén hasta Roma, el trabajo de amistad en cadena fue uno de los más importantes factores de influencia.

\section{La amistad como paso en la evangelizáción}

La amistad como un paso en la evangelización constituye un método de inspiración divina, que ha sido probado desde el mismo inicio de la historia de la iglesia primitiva. Los estudios sobre el crecimiento de la iglesia revelan que la amistad es uno de los eslabones importantes para un crecimiento sostenido de la iglesia. ${ }^{1}$ La amistad despierta el interés por la persona, prepara la voluntad para dar y compartir lo que abarca la relación humana, porque la amistad auténtica es uno de los valores más genuinos dentro del ser humano. ${ }^{2}$

Las investigaciones revelan que aproximadamente el 60 por ciento de los adultos bautizados en la Iglesia Adventista tuvo su primer contacto con la iglesia mediante familiares, amigos o vecinos adventistas. ${ }^{3}$ Esto comprueba el hecho de que la gente más de una vez es atraída a la iglesia por la amistad. De esta manera es evidente la importancia de la amistad en el proceso de la evangelización, desde la perspectiva divina y humana.

Gottfried Oosterwal dice que existen agencias que influyen para que personas no adventistas conozcan la iglesia. Tales agencias y el porcentaje de influencia que ejercen se muestran en las tablas 1 y 2 . Puede verse que el mayor porcentaje de personas conoció

${ }^{1}$ Joel Comiskey, La explosión de los grupos celulares en los hogares (Terrasa, Barcelona: CLIE, 2000), 132.

${ }^{2}$ Ayala, 71 .

${ }^{3}$ Gottfried Oosterwal, Patterns of SDA Church Growth in North America (Berrien Springs: Andrews University Press, 1974), 40, 41. 
la iglesia por medio de de sus amigos (43 por ciento). Asimismo el mayor porcentaje (40 por ciento) dijo haber entrado a la iglesia por medio de amigos adventistas.

\section{TABLA 1}

\section{PERSONAS QUE CONOCIERON LA IGLESIA ADVENTISTA MEDIANTE DIFERENTES AGENCIAS}

\begin{tabular}{|l|r|}
\hline Agencias & $\mathbf{\%}$ \\
\hline Amigos y vecinos & 43 \\
\hline Familiares & 24 \\
\hline Publicaciones adventistas & 13 \\
\hline Programas de radio y televisión & 4 \\
\hline Servicios a la comunidad & 4 \\
\hline Pastores adventistas & 3 \\
\hline Evangelismo público & $2-3$ \\
\hline Otros & $7-8$ \\
\hline
\end{tabular}

Gottfried Oosterwal, Patterns of SDA Church Growth in North America (Berrien Springs: Andrews University Press, 1974), 40, 41.

Según Osterwal, no menos del 67 por ciento de los miembros que se han unido a la Iglesia Adventista sin tener antecedentes adventistas, se han relacionado por primera vez con el mensaje adventista mediante vecinos, amigos, familiares y conocidos. ${ }^{1}$

Descubrir estas relaciones entre adventistas y los que no lo son constituye una oportunidad para fortalecer programas de capacitación en el área de evangelismo de la amistad, en la iglesia local o a nivel distrital, haciendo provisión para que la mayoría de los miembros bautizados puedan asistir y participen de todas las instrucciones que se ofrezcan. Esto fortalecerá el trabajo misionero de la iglesia y muchas personas podrán

\footnotetext{
${ }^{1}$ Oosterwal, 40, 41.
} 
conocer el evangelio.

TABLA 2

PERSONAS QUE ENTRARON A LA IGLESIA POR MEDIO DE AMIGOS ADVENTISTAS

\begin{tabular}{|l|c|}
\hline Agencias & $\%$ \\
\hline Amigos y vecinos & 40 \\
\hline Pastores adventistas & 21 \\
\hline Familiares & 17 \\
\hline Evangelismo público & 13 \\
\hline Escuelas adventistas & 9 \\
\hline Publicaciones adventistas & 7 \\
\hline Programa de radio y televisión & 7 \\
\hline Escuelas radiopostales & $2-3$ \\
\hline Otros & $2-3$ \\
\hline
\end{tabular}

Gottfried Oosterwal, Patterns of SDA Church Growth in North America (Berrien Springs: Andrews University Press, 1974), 40, 41.

Según Bakke y Hart, la mayor parte de los parientes y amigos de una persona recientemente bautizadas no son miembros de la iglesia. ${ }^{1}$ Ésta también es otra razón para implementar un programa permanente de evangelismo de la amistad.

Los nuevos conversos necesitan ser instruidos y atendidos por los demás miembros, para que aumenten en conocimiento y en amor a la verdad y crezcan hasta la plena estatura de hombres y mujeres en Cristo. Deben ser rodeados por las influencias más favorables al crecimiento espiritual. ${ }^{2}$

Una parte vital de este aliento es el compañerismo con otros que están disfrutando de la comunión con Cristo. Ésta es una manera de despertar en los nuevos

${ }^{\mathrm{I} B a k k e}$ y Hart, 14.

${ }^{2}$ White, El evangelismo, 258. 
miembros el deseo de compartir con otros el evangelio. Cuando los nuevos conversos no encuentran el compañerismo y la amistad que necesitan en la familia de la iglesia, generalmente dejan la iglesia después de un corto tiempo. ${ }^{1}$

Uno de los problemas que existe en la iglesia es la tendencia en los miembros antiguos de formar una especie de club cerrado al que no pueden ingresar los nuevos miembros. Según James Zackison, los antiguos, al dar preferente atención a su círculo de amigos, olvidan que los nuevos son como un pobre en el palacio. ${ }^{2}$

Según los estudios realizados, las impresiones que perduran se captan en los primeros treinta segundos. Si la persona decide regresar a la iglesia o no, toma apenas cinco minutos. ${ }^{3}$ Por eso, una cosa es traer una gran cantidad de nuevas personas a la iglesia, y otra muy diferente es proveerles el sustento emocional y espiritual que necesitan para permanecer allí.

Importancia del compañerismo cristiano

El apóstol Pablo, escribiendo a los Filipenses, pone énfasis en el compañerismo cristiano que debe reinar entre los miembros de la iglesia. "Nada hagáis por contienda o por vanagloria; antes bien con humildad, estimando cada uno a los demás como superiores a él mismo; no mirando cada uno por lo suyo propio, sino cada cual también por lo de los otros. Haya, pues en vosotros este mismo sentir que hubo en Cristo Jesús"

\footnotetext{
${ }^{1}$ Christian A. Schwarz, Desarrollo natural de la iglesia (Terrassa, Barcelona: CLIE, 1996), 71.

${ }^{2}$ James W. Zackrison, Poder para testificar (Buenos Aires: Casa Editora Sudamericana, 1993), 45. 1986), 132.

${ }^{3}$ Jorge Pradas, Congregados para darle gloria (Terrassa, Barcelona: CLIE,
} 
(Fil. 2:3-5). El consejo de Pablo no se cumple sólo mediante nuestras ofrendas generosas. La gente tiene necesidades espirituales y emocionales. Ellos anhelan amistad, comprensión, alguien que esté dispuesto a escucharlos y brindarles una palabra de aliento.

Una de las características de la iglesia primitiva fue el establecimiento de grupos de amistad. Los miembros solían reunirse en sus hogares. En realidad, las primeras iglesias fueron iglesias de hogar. El apóstol Pablo hace referencia a este hecho. "Saludad también a la iglesia de su casa. Saludad a Epeneto, amado mío" (Ro. 16:5). "Las iglesias de Asia os saludan. Aquila y Priscila, con la iglesia que está en su casa, os saludan mucho en el Señor" (1Co. 16:19). "Saludad a los hermanos que están en Laodicea, y a Ninfas y a la iglesia que está en su casa" (Col. 4:15).

Los creyentes comían juntos, compartían sus alegrías y tristezas y también sus bendiciones materiales, especialmente con los más necesitados. "Todos los que habían creído estaban juntos, y tenían en común todas las cosas; y vendían sus propiedades y sus bienes, lo repartían a todos según la necesidad de cada uno" (Hch. 2:44-45). La amistad cristiana fue una razón por la cual la iglesia primitiva retenía a sus miembros y aumentaba en nuevos miembros.

San Pablo, refiriéndose a los miembros de la iglesia de Macedonia, destaca el interés de participar en el compañerismo cristiano: "Pidiéndonos con muchos ruegos que le concediésemos el privilegio de participar en este servicio para los santos" (2 Co. 8:4). Los macedonios consideraban la necesidad de sus hermanos de Jerusalén como si fuera suya. Para ellos, pertenecer a la gran familia cristiana significaba participar en una causa común con los demás cristianos en el sacrificio, en el sufrimiento, en la pobreza y en la 
ayuda a otros. ${ }^{1}$

El texto griego de la última parte del mismo versículo dice literalmente: "La koinonia del servicio para los santos". La palabra koinonia, significa comunión, compañerismo, participación en común (de koinos, común). ${ }^{2}$ Este mismo concepto se traduce como compañerismo en Gá. 2:9, "Reconociendo la gracia que me había sido dada, Jacobo, Cefas y Juan, que eran considerados como columnas, nos dieron a mí y Bernabé la diestra en señal de compañerismo, para que nosotros fuésemos a los gentiles, y ellos a la circuncisión".

El vocablo koinonia aparece 20 veces en el Nuevo Testamento. Muy utilizado dentro de la iglesia cristiana primitiva, adoptó diversos matices. Incluye otros significados como asociación, camaradería y vínculo afectivo. Dentro del plano de las ideas abstractas, describía la prueba de de la unidad hermanable. ${ }^{3}$ Esta palabra se aplica con el sentido de compartir, participar juntos y contribuir, en Fil. 1:5 y Ro. 15:26. Éste es un ejemplo clásico de compañerismo para dar y hacer que las personas se sientan bien. La amistad, como resultado de nuestro compañerismo con Cristo, hará que las personas se queden en la iglesia y sean cristianos maduros.

Finalmente San Pedro también enfatiza la importancia de la amistad, para la consolidación de la iglesia: "Y... sed todos de un mismo corazón, compasivos,

1"Participar" [2 Corintios 8:4], Comentario biblico adventista, 7 vols., ed. F. D. Nichol, trad. V. Ampuero Matta (Boise: Publicaciones Interamericana, 1978-1990), $6: 885$.

${ }^{2}$ Vine, 276.

${ }^{3}$ William F. Arndt y F. Wilbur Gingrich, $A$ Greek-English Lexicon of the New Testament and Other Early Christian Literature (Chicago: University of Chicago Press, 1957), ver "koinonia". 
amándoos fraternalmente, misericordiosos y amigables" (1 P. 3:8).

Una iglesia amistosa cultiva el compañerismo y comparte con los necesitados. Sus integrantes comen juntos, realizan actividades en grupo y se esfuerzan por el trabajo misionero. Una iglesia amistosa retiene a sus miembros, porque la gente se siente cómoda dentro de un ambiente amigable.

\section{Preparación para realizar el evangelismo de la amistad}

A diferencia de otros estilos de evangelización, el evangelismo de la amistad requiere tiempo; es un proceso que no se determina por etapas. Tiene más que ver con el grado de sinceridad al ofrecer amistad con el interés de compartir el evangelio con los amigos.

Para tener buen éxito en la noble tarea de evangelizar por medio de la amistad, debemos tener una relación correcta con nuestro Dios. No es posible conducir a otros a Jesús a menos que él esté a nuestro lado. Esta preparación necesaria para ganancia de amistades incluye ponernos en armonía Dios y los demás por medio de la presencia del Espíritu Santo en nuestro interior. ${ }^{1}$ Antes de ir a conquistar el corazón de otros, debemos permitir que el poder del Espíritu Santo obre en nosotros para ser personas de oración y conducta sincera.

Es posible que hayamos olvidado que el fruto del Espíritu Santo constituye la parte más importante del éxito en la ganancia de las almas. Sin la armonía que sólo el Espíritu Santo puede producir en nosotros, el testimonio que demos al mundo no surtirá

\footnotetext{
${ }^{1}$ White, Obreros evangélicos, 301.
} 
ningún efecto. ${ }^{1}$

Resaltando la importancia del poder del Espíritu Santo en la predicación del evangelio, Jesús dijo al respecto: "Pero recibiréis poder, cuando haya venido sobre vosotros el Espíritu Santo, y seréis testigos en Jerusalén, en toda Judea, en Samaria y hasta lo último de la tierra" (Hch. 1:8).

Elena G. de White declara: "Aunque hemos de trabajar fervorosamente para la salvación de los perdidos, también debemos tomar tiempo para la meditación, la oración y el estudio de la Palabra de Dios. Es únicamente la obra realizada con mucha oración y santificada por el mérito de Cristo, la que al fin habrá resultado eficaz para el bien".2

A continuación argumenta: "Visitad a vecinos de una manera amigable y trabad relaciones con ellos". "Id a vuestros vecinos visitándolos uno por uno, y acercaos a ellos hasta que sus corazones sean calentados por vuestro interés y vuestro amor abnegado. Simpatizad con ellos, orad con ellos, vigilad las oportunidades de hacerles bien". ${ }^{4}$

De esta manera la amistad es, para Win y Charles Arn, más que una herramienta de evangelización. Es compartir con los no creyentes el estilo de vida de un cristiano que ha experimentado el amor transformador de Cristo. ${ }^{5}$

Cada cristiano puede practicar evangelismo de la amistad, al mostrar a sus

${ }^{1}$ Floyd O. Rittenhouse, Muéstrame tus caminos (Miami: Interamerican Publishing Association, 1983), 311.

${ }^{2}$ White, El Deseado de todas las gentes, 329.

${ }^{3}$ White, El ministerio de la bondad, 83.

${ }^{4}$ White, Servicio cristiano eficaz, 145.

${ }^{5}$ Win Arn y Charles Arn, El plan del maestro para hacer discípulos (Pasadena: Church Growth, 1982), 169. 
amigos y parientes su interés para hacerles un bien. Las buenas acciones abren puertas para nuevas amistades, y mantienen el interés para cultivar la confianza para hablar del evangelio a las personas que posiblemente no se serán alcanzadas de otra manera.

Se debe recordar entonces, que la mayoría de la gente viene a Cristo por un proceso que en muchas ocasiones comienza con una buena acción.

\section{Maneras prácticas para la evangelización por la amistad}

Como en cualquier otro estilo de evangelismo, la evangelización por la amistad demanda mucha paciencia, fe, tiempo pasado sobre nuestra rodillas, tiempo para practicar la cortesía y disposición para servir a los demás. ${ }^{1}$ A continuación se presentan algunas maneras prácticas para realizar este tipo de evangelización.

1. Ore a Dios por un amigo en especial. El ministerio de la oración personal en favor de otros constituye un elemento poderoso en la predicación del evangelio. En el mundo existen muchas personas que luchan con sus debilidades y preocupaciones. Elena G. de White reconoció este aspecto cuando escribió: "En todas partes hay corazones que claman por algo que no poseen. Suspiran por una fuerza que les dé dominio sobre el pecado, una fuerza que los libre de la esclavitud del mal, una fuerza que les dé vida y paz". ${ }^{2}$ Ruegue a Dios regularmente para que bendiga a su amigo y a su amistad y se abra la puerta para la predicación del evangelio. El apóstol Pablo pidió a los miembros de la iglesia de Colosas que oraran "para que el Señor nos abra puertas para la palabra, a fin de dar a conocer el misterio de Cristo" (Col. 4:3).

2. Cultive su amistad. Busque las maneras de ayudar y de animar a su amigo.

\footnotetext{
${ }^{1}$ Sahlin, 13.

${ }^{2}$ White, Ministerio de curación, 102.
} 
Recuerde los cumpleaños y los aniversarios. Comparta sus épocas de alegrías y celebraciones. El principio bíblico menciona: "El hombre que tiene amigos ha de mostrarse amigo" (Pr. 18:24). Es decir, debemos interesarnos en los demás y ellos se interesarán en nosotros. Muéstrese amigo con los demás y ellos harán lo mismo. ${ }^{1}$

3. Acepte sus invitaciones. Cristo no se rehusó a mezclarse con otros en amable trato. ${ }^{2}$ La aceptación y la asistencia a las reuniones de nuestras amistades no debe poner en riesgos nuestros principios. En este aspecto tenemos el ejemplo dado por Jesús. Elena G. de White comenta al respecto: "Aceptaba las invitaciones de unos y otros, asistía a sus banquetes, se familiarizaba con sus intereses y ocupaciones para abrirse camino a sus corazones y darles a conocer las riquezas imperecederas". ${ }^{3}$ Estas acciones nos permiten conquistar los corazones de las personas y ganar su aprecio. Debemos olvidarnos de nosotros mismo y tratar siempre de encontrar oportunidades de animar a los demás, aliviar sus penas y cargas mediante actos de afectuosa bondad y pequeñas muestras de amor. ${ }^{4}$

4. Escuche atentamente. Escuchar es otro método efectivo para conquistar la confianza y el aprecio de los demás. No es posible ayudar a las personas a llevar sus cargas sin estar dispuestos a escucharlas en sus necesidades. Escuchar con atención requiere autodisciplina y real interés en la persona y en sus problemas. El arte de

\footnotetext{
'Dorothy Eaton Watts, El don de la amistad (Miami: Asociación Publicadora Interamericana, 1995), 8. 404.

${ }^{2}$ White, Mensajes para los jóvenes (Mountain View, CA: Pacific Press, 1977),

${ }^{3}$ White, Ministerio de curación, 15.

${ }^{4}$ Arthur G. McPhee, Friendship Evangelism: The Caring Way to Share Your Faith (Grand Rapids: Zondervan, 1978), 55.
} 
escuchar no consiste sólo en oír. Es una experiencia activa en la que se participa mientras se presta atención a lo que el otro está diciendo. Al lograr la capacidad de saber escuchar, el oyente no abandona sus convicciones ni pierde su identidad; sencillamente aprende a concentrar su atención en la otra persona como un acto amoroso. Esto tiene efectos maravillosos en las relaciones. ${ }^{1}$

5. Sea honesto y sincero. No deben utilizarse máscaras para esconder la verdadera identidad. Debe haber libertad para que la persona se muestre tal cual es.

6. Pida un favor. Cada vez que una persona inicia un contacto, la otra persona sé esta preguntando “¿Qué es lo que esta persona quiere?” Si usted no contesta esta pregunta, la persona la contestará por usted. ${ }^{2}$ Pedir un sencillo favor puede abrir puertas que de otro modo no se abrirían. En su trato con la mujer samaritana, Jesús utilizó este método. "Vino una mujer de Samaria a sacar agua; y Jesús le dijo: Dame de beber" (Jn. 4:7). Según Elena G. de White, "el odio que reinaba entre los judíos y los samaritanos impidió a la mujer ofrecer un favor a Jesús; pero el Salvador estaba tratando de hallar la llave de su corazón, y con el tacto nacido del amor divino, él no ofreció un favor, sino que lo pidió. El ofrecimiento de un favor podría haber sido rechazado; pero la confianza despierta confianza"3

7. Sea positivo y alegre. Debemos cultivar el hábito de sonreír, pues es muy agradable la compañia de quienes son positivos y alegres. La escritora Elena G. de White comenta al respecto: "Hay misteriosos vínculos que ligan las almas, de manera que el

${ }^{1}$ Cecil G. Osborne, Llevarse bien es un arte (Miami: Vida, 1983), 32.

${ }^{2}$ Nancy Van Pelt, Sin reservas: El arte de comunicarse (Madrid: Safeliz,1996), 41.

${ }^{3}$ White, El Deseado de todas las gentes, 155-156. 
corazón de uno responde al del otro. El uno adopta inconscientemente las ideas y el espiritu del otro. Este trato puede ser una bendición o una maldición". 1

8. Cumpla fielmente los compromisos. El sentido de responsabilidad enaltece al individuo y lo hace digno de confianza. Esta cualidad en las relaciones humanas determina el grado de credibilidad que se le pueda otorgar a una persona. ${ }^{2}$ La Biblia aconseja específicamente a este respecto, "Mejor es que no prometas, y no que prometas y no cumplas" (Ec. 5:5).

En la predicación del evangelio se puede usar diferentes métodos. Sin embargo la predicación por medio de la amistad es práctica, es un trabajo de persona a persona, tiene que ver con las personas a quienes se puede hablar cada día. Esto incluye a los compañeros de trabajo, a las personas que atienden en el supermercado o en la estación de servicio, a los vecinos, al médico de la familia, al farmacéutico, al oculista, al mecánico y al agente de seguros. ${ }^{3}$ Es por eso que al tratar con este tipo de personas para ganar su amistad, se requiere brindar nuestra simpatía con sinceridad, y tomar en cuenta los principios señalados en esta sección. De esta manera se logrará tener éxito en la noble tarea ganar de almas para el reino de los cielos.

${ }^{1}$ White, Mensajes para los jóvenes, 409.

${ }^{2}$ Carlos Tornero Díaz, La actitud del hombre frente a la vida (Buenos Aires: Porrúa, 1991), 81.

${ }^{3}$ Sahlin, 1, 2. 


\section{CAPÍTULO IV}

\section{PROGRAMA DE EVANGELIZACIÓN POR LA AMISTAD}

El evangelismo de la amistad requiere buscar maneras prácticas y eficaces para compartir el evangelio de Cristo con nuestros parientes y amigos. También se enfatizan la importancia y la necesidad de ser amables con nuestros semejantes, para abrir la puerta del corazón para la entrada del evangelio. Además se señala que la amabilidad es una de las virtudes que cada cristiano debe manifestar en sus relaciones personales, como fruto del Espíritu Santo.

Este capítulo presenta la información necesaria para la realización de un programa sobre evangelismo de la amistad en una iglesia local. Se espera que este material ayude a los miembros de la iglesia, como también a los dirigentes, para ser amables y amistosos en sus relaciones con visitas, nuevos miembros y miembros en potencia, para lograr un mayor crecimiento de la feligresía, al usar estas técnicas en la predicación del evangelio.

El capítulo está dividido en tres secciones: preparación del programa, implementación del programa y evaluación del programa.

\section{Preparación del programa}

Para la preparación del programa se usan los materiales conocidos por la hermandad para hacer más fácil el aprendizaje y la aplicación; la Biblia, los escritos de 
Elena G. de White y otros materiales relacionados con el tema.

Este programa consta de cinco sesiones. En la primera sesión se define qué es el evangelismo de la amistad. En la segunda sesión se explica la base bíblica para el evangelismo de la amistad. En la tercera sesión se presenta la importancia de la amabilidad. En la cuarta sesión se muestra la preparación espiritual para realizar este tipo de evangelismo. Y en la quinta sesión se presentan maneras prácticas para evangelizar por medio de la amistad. Cada sesión tendrá una duración de 45 minutos.

El contenido de cada sesión se limitará a los principios básicos del evangelismo de la amistad que sean comprensibles para los miembros de la iglesia. Además se considerará cual es el propósito al presentarlo, hacia quien va dirigido este programa, la longitud de cada sesión. Todo esto dependerá del lugar y de las circunstancias del entorno de la iglesia donde se desarrolle el programa.

\section{Propósito y objetivos}

El propósito de este programa es capacitar a los miembros y dirigentes de la iglesia local, para mostrar amabilidad y buen trato en las relaciones personales, y de esta forma preparar a sus amigos y parientes para la aceptación del evangelio de manera sencilla.

Por lo práctico del programa, no se profundiza en asuntos teológicos, ni se pretende analizar asuntos doctrinales. Sin embargo, se ofrecen los principios fundamentales para la evangelización por la amistad que cualquier miembro puede usar.

Los objetivos específicos del programa evangelización por la amistad para miembros y dirigentes de la iglesia, son los siguientes:

1. Ofrecer información acerca del evangelismo de la amistad. 
2. Instruir a los participantes en los principios básicos de la evangelización por la amistad.

3. Enseñar a los miembros de iglesia cómo ser amables con sus semejantes.

4. Enseñar a los miembros de la iglesia maneras prácticas del evangelismo de la amistad.

5. Motivar a los miembros de la iglesia para participar en la predicación del evangelio por medio de la amistad y las buenas relaciones personales.

\section{Planeamiento}

\section{Autorización de las juntas correspondientes}

El pastor debe consultar con los ancianos acerca de la realización del programa, mostrando los beneficios que traerá a la iglesia. Una vez que tenga el consenso de los ancianos, el pastor debe someter el asunto a la junta directiva de la iglesia para contar con un voto de recomendación, que será propuesto a la junta administrativa de la iglesia. El voto debe incluir la fecha de la realización y el nombre del instructor.

Contando con el voto de la junta directiva, el pastor presenta el plan a la junta administrativa de la iglesia. En esta junta el pastor enfatiza los beneficios que este programa traerá a la iglesia, y además anuncia quien será el instructor y la fecha para realizar el programa. Se debe acordar también, que los detalles sean delegados a la junta directiva.

Entre las cosas que la junta directiva debe atender están los siguientes: requisitos para participar, nombrar la comisión coordinadora, la cual a su vez nombra las otras comisiones necesarias. Cuando todos estos asuntos están arreglados, el pastor deberá analizar con el instructor el programa completo y definir las modalidades que se seguirán. 


\section{Instructores}

El programa ha sido diseñado para ser presentado y desarrollado por el pastor del distrito, $\mathrm{o}$ algún anciano de la iglesia local que esté capacitado para ello. También puede ser desarrollado por un departamental del campo local. Siendo que éste es un programa para la iglesia local, se espera que el pastor del distrito sea el más comprometido y el que muestre más interés en su implementación.

Por la naturaleza del programa, cualquier pastor de distrito puede compartirlo con los dirigentes de las iglesias de su distrito, y una vez que ellos lo conozcan, pueden en consenso decidir quien lo puede realizar en cada iglesia del distrito. Ésta sería otra opción para definir quienes serán los instructores. Además, por la experiencia y preparación de los dirigentes de la asociación, también se les puede pedir que ellos sean los instructores del programa.

\section{Quiénes tomarán el curso}

Este programa ha sido preparado para todos los miembros de la iglesia que, de alguna manera, han demostrado o sentido el deseo de compartir el evangelio con sus amigos, parientes o vecinos por medio de la amistad. Sin embargo, también lo puede recibir cualquier miembro que asiste de manera regular a los cultos de la iglesia.

Además, se espera que todos los dirigentes de cada iglesia del distrito sean los primeros en tomar el curso para poder impulsarlo como parte de su responsabilidad.

\section{Lugar, materiales y equipo}

Por la naturaleza práctica de este programa, no se prepara un manual del participante. Se presenta utilizando el sistema de Power Point, si se tiene al alcance el equipo necesario. En su defecto, se preparan transparencias (acetatos) para utilizar un 
retroproyector. Si se presenta el programa en una iglesia rural, se recomienda usar un rotafolio que contenga todo el material del curso.

Por ser este programa para todos los miembros y dirigentes de la iglesia, el lugar de reuniones es la nave principal de la iglesia local. Si embargo, es posible que exista un lugar apropiado para celebrar el programa, que ofrezca todo lo necesario para alcanzar los objetivos. En este caso la iglesia lo decide.

\section{Promoción}

La comisión de promoción elabora carteles para anunciar el programa y se colocan en el tablero principal de la iglesia para que todos los miembros se enteren con anticipación. Además, se anuncia desde el púlpito en los días regulares de culto. El anuncio debe incluir: el horario de las reuniones, como inscribirse, el nombre del que va a presentar el programa, el lugar donde se realizará y los requisitos para tomar el curso. Los requisitos pueden ser los siguientes: ser miembro bautizado de la iglesia, cubrir la cuota de inscripción (si se solicita), asistir a todas las sesiones de trabajo, comprometerse a practicar los principios del programa y tener buena disposición de participación.

\section{Inscripción}

Quince días antes de la realización del programa, y una vez que se conozcan los requisitos para tomar el curso, la comisión de inscripción realiza esta tarea. Además, esta comisión debe informar a los participantes, el día, la hora y el lugar de las reuniones.

En el apéndice se incluye el formulario de la inscripción. Si es necesario, por las circunstancias de la iglesia donde se presenta el programa, deben hacerse las modificaciones que se requieran. 


\section{Implementación}

En esta sección se presenta la manera de implementar el programa en la iglesia local. Se describe el contenido de las cinco sesiones y las tareas prácticas que los alumnos deben realizar. También se sugieren distintas modalidades de entrega del seminario.

Desarrollo del programa

Ahora todo está listo para comenzar el programa "Evangelismo por la amistad". La comisión de inscripción ya entregó la lista de los participantes. El lugar y el equipo están listos. El instructor se ha preparado con suficiente tiempo. Es el momento para iniciar el programa.

Luego de dar la bienvenida el instructor reparte una hoja de preguntas sobre el evangelismo de la amistad. Los participantes las llenarán y las devolverán. Servirán para captar la curiosidad y como base de la evaluación que se describe en la tercera parte de este capítulo.

Este programa consta de cinco sesiones de 45 minutos cada una, y contiene los principios básicos para el evangelismo por medio de la amistad. El contenido de cada sesión no contempla ningún asunto doctrinal. Tampoco se incluye información sobre evangelismo público o la preparación de sermones, por no ser asuntos que no están dentro . del evangelismo de la amistad. Más bien, cada sesión ofrece detalles prácticos y maneras sencillas para la presentación del evangelio por medio de la amistad y el compañerismo cristiano, que cada miembro podrá utilizar de manera personal.

El instructor ocupa la mayor parte del tiempo. Sin embargo; al finalizar cada sesión de trabajo el instructor da un periodo suficiente para que los alumnos participen 
con sus aportaciones o haciendo preguntas. Puede usar los materiales de esta tesis y en especial del apéndice.

\section{Descripción de cada sesión}

\section{Evangelismo de la amistad}

Esta sesión del programa contiene tres partes, cada una de las cuales consta de quince minutos. En la primera se define el significado de "evangelismo de la amistad". El estudio comienza haciendo énfasis en el mandato divino presentado en Mt. 24:14. Se analiza la aplicación práctica de este mandato misionero, y se mencionan algunas maneras de predicar el evangelio, incluyendo por supuesto el evangelismo de la amistad. Con el propósito de fijar en la mente de los participantes el significado de "evangelismo de la amistad" se mencionan algunos conceptos, incluyendo el que utiliza Monte Sahlin, al respecto. ${ }^{1}$

También se hace referencia a algunas definiciones de Elena G. de White, relacionadas con el tema; por ejemplo: "Si quisiéramos humillarnos antes Dios, ser amables, corteses y compasivos, se producirían cien conversiones a la verdad allí donde se produce una ahora"2. "El poder de la sociabilidad, santificado por el Espíritu de Cristo, debe mejorar a fin de ganar almas para el Salvador". ${ }^{3}$ Al final de esta parte, se invita a los participantes a reflexionar sobre esta manera de evangelizar.

En la segunda parte se muestran algunos ejemplos bíblicos donde se enfatiza la ganancia de almas a través del compañerismo y la amistad, entre parientes y amigos. Se

${ }^{1}$ Sahlin, Friendship Evangelism, 6.

${ }^{2}$ White, El ministerio de la bondad, 127.

${ }^{3}$ Elena G. de White, Mente, carácter y personalidad (Buenos Aires: Casa Editora Sudamericana, 1990), 2:648. 
considera la experiencia de la conversión del carcelero de Filipos (Hch.16:30-34), la preparación que hace Cornelio para la llegada de Pedro (Hch. 10:24), la conversión de Lidia con su familia (Hch.16:14, 15). Se considera que la iglesia apostólica en gran medida creció a través del evangelismo de la amistad.

"Cómo hacer amigos" es el tema de la tercera parte. Aquí se presentan algunos principios del arte de ganar amigos. Se da énfasis a la importancia de las buenas relaciones buenas humanas. Se menciona que como cristianos debemos tener amigos, no sólo dentro de la iglesia, sino en el medio donde vivimos. ${ }^{1}$

Al finalizar esta sesión se invita a los participantes a comprometerse a mostrar una actitud amable, un espíritu alegre y pronunciar palabras corteses en el diario vivir. ${ }^{2}$

\section{Base para el evangelismo de la amistad}

La primera parte de esta sesión se inicia presentando un estudio de algunas referencias bíblicas que muestran que la amistad es un factor útil en la predicación del evangelio. Se estudian algunos versículos como Prov. 18:24, Jn. 15:15, Lc. 10:36, 37, y 1 P. 3:8, entre otros.

Además se refuerza este argumento bíblico con algunos pensamientos de Elena G. de White, como los siguientes: "Mediante las relaciones sociales es como el cristianismo se trasmite al mundo". "Por medio del trato social se contraen relaciones y se forman amistades que unen los corazones y crean un ambiente de amor que agrada al

\footnotetext{
${ }^{1}$ Watts, 8 .

${ }^{2}$ White, Mente carácter y personalidad, 2:595.

${ }^{3}$ White, Manuscrito 59.
} 
cielo". ${ }^{2}$ Al finalizar la sesión se motiva a los participantes a practicar estos principios.

En el segundo período de esta sección del programa, se estudia el compañerismo de la iglesia apostólica como un ejemplo de evangelismo de la amistad. Se hace referencia al hecho de que las iglesias eran establecidas y funcionaban en casas (Ro. 16:5; 1 Co. 16:19; Col. 4:15). El propósito de esta parte es mostrar a los hermanos el crecimiento de la iglesia en esa época, y motivarlos para implementar este tipo de evangelismo en su iglesia.

La última clase de esta sesión considera un análisis de la palabra koinonia, para conocer su significado y su aplicación en la iglesia del Nuevo Testamento. Se medita en algunos texto bíblicos donde se aplica este concepto; por ejemplo: Gál. 2:9, Hch. 2: 42$44 ; 2$ Co. $13: 14$.

Al finalizar la clase se presentan algunas sugerencias de actividades para fomentar el compañerismo entre los miembros de la iglesia.

\section{Importancia de la amabilidad}

En la primera parte se estudia el significado de la amabilidad, de manera general. El propósito es motivar a la hermandad a practicar una conducta amable en sus relaciones con las visitas, con los miembros en potencia y entre ellos mismos.

El segundo período tiene como propósito estudiar con los participantes, la amabilidad en la Biblia. Este periodo se divide en dos partes. En la primera, se hace referencia al concepto de la amabilidad en el Antiguo Testamento. Se analizan algunos casos en donde es utilizada en la vida práctica. Se relata la historia de José cuando sus hermanos van a Egipto por alimento y la manera como él los trata (Gn. 50:19-21).

\footnotetext{
${ }^{1}$ White, Testimonies for the Church, 6:172.
} 
Además se analiza la actitud de Moisés cuando interviene en defensa de las hijas del sacerdote de Madián, como un acto de amabilidad (Ex. 2:17). También se estudia el acto de Abigail, esposa de Nabal, como una acción de amabilidad, cuando salió al encuentro de David (1 S. 25:12-35). Termina esta sección repasando los principios de amabilidad contenidos en el libro de Proverbios.

En la segunda parte se analiza el concepto de amabilidad en el Nuevo Testamento. Aquí de igual forma se estudia el vocablo utilizado. Se reflexiona sobre algunas citas donde es usada la palabra y su aplicación, como 1 Ti. 3:3; Tit. 3:2; Stg. 3:17; Fil. 4:5, entre otros.

Al finalizar esta sección se refuerza el concepto bíblico de la importancia de ser amables con todos y se invita a los hermanos a comprometerse a practicar estos principios en sus relaciones personales.

Elena G. de White y la amabilidad; éste es el titulo del tercer módulo. Aquí se analiza lo que esta autora dice en relación al tema. El estudio da inicio analizando la importancia que le da a la amabilidad. Para enfatizar el tema, se presenta una de las referencias que ella menciona: "El cultivo de una cortesía uniforme, la voluntad de tratar a otros como desearíamos ser tratados nosotros, eliminaría la mitad de las dificultades de la vida".

La religión y la amabilidad es otro asunto que se trata en esta parte. De igual forma se seleccionan algunos párrafos para conocer la opinión de White al respecto. Al concluir el estudio de esta sección se realiza un bando de oración con todos los participantes para pedir a Dios que ayude a ser amables como parte de nuestra vida cristiana.

\footnotetext{
${ }^{\mathrm{I}}$ White, El ministerio de la bondad, 161.
} 
Siendo que es importante conocer la opinión de otros autores en relación a la amabilidad y su aplicación en la vida diaria, la quinta sesión se denomina "la amabilidad según otros autores". Aquí se presenta a los participantes lo que dice la literatura secular en relación al tema. El propósito de esta parte es que los cursantes comparen el significado cristiano y secular de la amabilidad y como se aplica en ambos casos.

La quinta y última parte de esta sesión se llama "el evangelismo y la amabilidad". El objetivo de esta clase es enseñar a los hermanos algunas maneras prácticas de predicar el evangelio por medio de actos amables.

Se estudia la importancia de las palabras y el efecto que éstas tienen en las personas. Utilizando lo que dice Elena G. de White en relación al tema, se señala lo siguiente "Son las palabras agradables y llenas de simpatía, la manifestación del amor desinteresado por las almas, lo que romperá las barreras del orgullo y mostrará a los incrédulos que poseemos el amor de Cristo; y entonces la verdad se abrirá camino al corazón".

También se enfatiza lo útil que resulta la amabilidad como medio para predicar el evangelio; y estar dispuestos servir a los demás. Se presenta el servicio como un principio del cielo basado en el lema del ministerio de Cristo en su ministerio terrenal (Mr. 10:43-45). También se refuerza esta parte con el comentario de White: "El espíritu de trabajo desinteresado por otros da al carácter profundidad, firmeza, y amabilidad parecida a la Cristo; trae paz y felicidad al que lo posee". ${ }^{2}$

Para finalizar esta parte se hace un ejercicio con los participantes donde se practican las palabras amables, $y$ algunos actos de bondad.

\footnotetext{
${ }^{1}$ White, El evangelismo, 462.

${ }^{2}$ White, El camino a Cristo, 80.
} 


\section{Preparación espiritual para el evangelismo de la amistad}

Esta sesión se divide en dos partes. La primera parte se llama "nuestra relación con Dios”. Aquí se enfatiza la importancia de una vida devocional personal con Dios, como preparación indispensable para la predicación del evangelio. Se enfatiza la declaración de Elena G. de White: "Aunque hemos de trabajar fervorosamente para la salvación de los perdidos, también debemos tomar tiempo para la meditación, la oración y el estudio de la palabra de Dios". ${ }^{1}$ El propósito es invitar a los hermanos a consagrarse al Señor cada día.

La segunda parte se denomina "Guiados por su Espíritu”. Aquí se conscientiza a los participantes de la necesidad de ser dirigidos por este Poder, para tener éxito en la predicación. Se repasa la experiencia de la iglesia apostólica en el día del Pentecostés (Hch. 2:1-4). Se reafirma la necesidad actual del poder del Espíritu Santo en la predicación. De esta manera los esfuerzos hechos por la conversión de los pecadores darán resultados.

$\mathrm{Al}$ final de esta parte se hace un llamado a todos los cursantes para renovar el compromiso con Dios de ser cristianos consagrados.

\section{Formas prácticas para la evangelización por la amistad}

Ésta es la última sesión del programa. Aquí se presentan algunas ideas practicas para la evangelización por la amistad. En primer lugar se le pide a cada participante que ore por un amigo o pariente en especial. Se refuerza este punto con la declaración de Elena G. de White al respecto: "En todas partes hay corazones que claman por algo que

\footnotetext{
${ }^{1}$ White, El Deseado de todas las gentes, 329.
} 
no poseen. Suspiran por una fuerza que les dé dominio por el pecado, una fuerza que los libre de la esclavitud del mal, una fuerza que les dé vida y paz".

Mandar una tarjeta el dia de cumpleaños es un detalle muy importante para mostrar el aprecio que se tiene por la persona. Se les recomienda a los participantes que con mucho cuidado y discreción consigan la fecha del cumpleaños de sus amigos y conocidos.

Aceptar las invitaciones a las reuniones sociales de sus amistades o parientes no cristianos es otra manera sencilla para demostrarles a las personas que nos interesan. Aquí se les muestra a los cursantes que Jesús asistía a las reuniones sociales a las que era invitado. White certifica esto de la siguiente manera: "Aceptaba las invitaciones de unos y otros, asistía a sus banquetes, se familiarizaba con sus intereses y ocupaciones para abrirse camino a sus corazones y darles a conocer las verdades imperecederas". ${ }^{2}$

Otra de las formas prácticas de evangelizar por medio de la amistad consiste en ser un buen vecino. En esta sección se les enseña a los hermanos la importancia de saludar a los vecinos y ofrecerles nuestros servicios cuando lo necesiten.

Visitar a nuestros amigos, parientes y vecinos cuando están enfermos u hospitalizados es una forma de decirles que nos interesa su bienestar y que estamos preocupados por su recuperación. En esta parte se les enfatiza a los participantes, lo relevante que resulta para las personas este acto y la manera de hacer estas visitas.

Para terminar esta participación, se les pide a los cursantes que participen mencionando otras maneras que en su entorno resulten útiles para evangelizar por la amistad.

\footnotetext{
${ }^{1}$ White, Ministerio de curación, 102.

${ }^{2}$ Ibíd, 15 .
} 
Modalidades de las presentaciones

El programa tiene una duración de seis horas incluyendo un periodo de convivencia en la clausura. Se puede ofrecer en cuatro posibles modalidades: un dia completo, un fin de semana completo, tres sábados de tarde o tres días de la semana, que pueden ser domingo, miércoles y viernes. En cualquier modalidad se debe cubrir el contenido completo del programa. El periodo de convivencia es muy importante, porque esta actividad refuerza los conocimientos que cada participante asimila durante las clases y le da la oportunidad de practicarlos. Estas diferentes modalidades permiten que, según las circunstancias, más personas puedan participar y el programa pueda ser de mayor utilidad para la iglesia.

\section{Un sólo día}

Por algunas circunstancias es posible que el instructor o la iglesia sólo pueda realizar el programa en esta modalidad, entonces el curso se imparte de manera intensiva. Las seis horas del programa completo se distribuyen de manera intercaladas con algunos periodos de descanso para hacer posible un mejor aprovechamiento. Se comienza por la mañana y se finaliza por.la tarde. Si se sigue este modelo, a medio día todos los participantes comen juntos y se realiza una actividad para fortalecer el compañerismo y la amistad.

Al realizar todo el programa en esta modalidad, el instructor deberá tener cuidado de exponer cada sesión de manera clara y precisa para que la asimilación de los conceptos por parte de los participantes sea lo mejor posible. De tal manera, al llevar a la práctica los principios que el curso contiene, éstos pueden ser utilizados correctamente y se obtienen los beneficios esperados. 


\title{
Por la mañana
}

\author{
9:00 - 9:10 Bienvenida y servicio de cantos. \\ 9:10 - 10:00 Primera sesión: Definiendo evangelismo de la amistad. \\ 10:00-10:10 Descanso. \\ 10:10 - 11:00 Segunda sesión: Base bíblica para el evangelismo de la \\ amistad. \\ 11:00-11:10 Descanso. \\ 11:10 - 12:00 Tercera sesión: Importancia de la amabilidad.
}

Por la tarde

3:00 - 3:10 Servicio de cantos.

3:10 - 4:00 Cuarta sesión: Preparación espiritual.

4:00 - 4:10 Descanso.

4:10 - 5:00 Quinta sesión: Maneras prácticas para el evangelismo de la amistad.

5:00-6:00 Evaluación.

6:00 - 7:00 Convivencia de la amistad.

Fin de semana completo.

Este programa se puede realizar en un fin de semana completo, es decir, se inicia el viernes y termina el domingo. Las cinco partes del programa se cubren durante los tres días. Se programan seis horas de instrucción, dos horas el viernes, dos el sábado por la tarde y dos el domingo. Al final de la presentación del programa se realiza una evaluación para conocer el aprovechamiento del curso. El domingo, para la clausura, se prepara una convivencia amistosa con todos lo participantes para practicar algunos 
principios aprendidos.

Viernes p. m.

7:00 - 7:30 Bienvenida e indicaciones generales.

7:30 - 8:20 Primera sesión: ¿Qué es evangelismo de la amistad?

8:20-8:40 Descanso.

8:40 - 9:30 Segunda sesión: Base bíblica para el evangelismo de la amistad.

Sábado p. m.

4:00 - 4:10 Bienvenida y servicio de cantos.

4:10 - 5:00 Tercera sesión: Importancia de la amabilidad.

5:00 - 5:10 Descanso.

5:10 - 6:00 Cuarta sesión: Preparación espiritual.

\section{Domingo p. m.}

5:00 - 5:10 Bienvenida y servicio de cantos.

5:10 - 6:00 Quinta sesión: Maneras prácticas para evangelizar por la amistad.

6:00-6:10 Descanso.

6:10-7:00 Evaluación.

7:00 - 8:00 Programa de convivencia.

\section{Tres días}

Esta modalidad permite usar los días de culto normales de la iglesia local sin alterar la programación de fin de semana. Sin embargo, el instructor debe estar seguro de 
que se realizó una buena promoción para asegurar la asistencia de los participantes. Al seguir esta forma se puede terminar el viemes por la noche con un programa de consagración y compromiso con Dios en el fiel cumplimiento de la misión de la iglesia.

Domingo p. m.

6:00 - 6:10 Bienvenida y servicio de cantos.

6:10 - 7:00 Primera sesión: Definiendo evangelismo de la amistad.

7:00-7:10 Descanso.

7:10 - 8:00 Segunda sesión: Bases bíblica para el evangelismo de la amistad.

Miércoles p. m.

6:00 - 6:10 Bienvenida y servicio de cantos.

6:10-7:00 Tercera sesión: Importancia de la amabilidad.

7:00-7:10 Descanso.

7:10-8:00 Cuarta sesión: Preparación espiritual.

Viernes p. m.

6:00-6:10 Bienvenida y servicio de cantos.

6:10-7:00 Quinta sesión: Maneras prácticas para el evangelismo de la amistad.

7:00 - 8:00 Evaluación y culto de consagración.

\section{Tres sábados de tarde}

Aunque el programa se puede completar en cualquiera de las modalidades ya mencionadas, también es posible que se presente en tres sábados de tarde. En esta 
modalidad, la instrucción se imparte dos horas cada sábado. De ser posible, se deja el cuarto sábado para la evaluación, la practica de algunos aspectos del programa y una reunión social para fortalecer los lazos de amistad y compañerismo entre los participantes.

$$
\text { Primer sábado p. m. }
$$

4:00-4:10 Bienvenida y servicio de cantos.

4:10 - 5:00 Primera sesión: ¿Qué es evangelismo de la amistad?

5:00-5:10 Descanso.

5:10 - 6:00 Segunda sesión: Base bíblica para evangelismo de la amistad.

$$
\text { Segundo sábado p. m. }
$$

4:00-4:10 Bienvenida y servicio de cantos.

4:10 - 5:00 Tercera sesión: Importancia de la amabilidad.

5:00-5:10 Descanso.

5:10 - 6:00 Cuarta sesión: Preparación espiritual.

Tercer sábado p. m.

4:00-4:10 Bienvenida y servicio de cantos.

4:10 - 5:00 Quinta sesión: Maneras prácticas para evangelizar por la amistad.

5:00-5:10 Descanso.

5:10-6:00 Evaluación.

6:00 - 7:00 Convivencia de la amistad. 
La asistencia

Debe mencionarse a los participantes lo indispensable que es la asistencia a cada sesión para logra un mayor aprovechamiento. Para darle la importancia que el programa requiere, conviene que el pastor del distrito esté presente en todas las sesiones.

\section{Clausura}

Al final del programa se tendrá una ceremonia de clausura donde se le entregará a cada participante un diploma por haber participado del curso. El programa de clausura debe ser sencillo. Se debe invitar a cada participante que pase al frente para recibir su diploma. Si se considera necesario, se tendrá un mensaje de consagración al servicio.

Este mensaje puede ser presentado por el pastor del distrito o algún invitado. Aunque el programa de clausura debe ser sencillo, sin embargo, este momento es muy importante para todos los que participaron en el seminario, ya que ahora cada uno de ellos hará un compromiso con Dios de practicar este plan evangelístico con sus parientes y conocidos.

Si la comisión organizadora en acuerdo con la iglesia preparan un momento de convivio después del programa de clausura para todos los participantes, esto contribuirá para terminar con un ambiente de compañerismo.

El propósito del presente programa de evangelización por la amistad es tener un efecto transformador en la mente de cada participante. Servirá para que se adopte un nuevo estilo de evangelismo a través de los lazos de amistad y compañerismo como parte de nuestra relación con Cristo, en nuestras relaciones personales. Se espera de que de esta manera la iglesia se comprometa a predicar el evangelio de una manera sencilla, especialmente a sus amigos, vecinos y parientes. A continuación se presenta una 
sugerencia para el programa de clausura.

Bienvenida (3 minutos)

Himno (3 minutos)

Oración (2 minutos)

Canto especial (3 minutos)

Presentación del orador (2 minutos)

Mensaje (20 minutos)

Entrega de diplomas (10 minutos)

Desafio (5 minutos)

Canto final ( 3 minutos)

Oración final (2 minutos)

\section{Entrenamiento práctico}

Después de que los participantes hayan tomado completo el curso, en cualquiera de las modalidades, se procede a la práctica. El entrenamiento será sólo sobre el evangelismo de la amistad. La primera actividad será hacer una lista de las amistades, vecinos o parientes no cristianos. Una vez hecha la lista, cada hermano elegirá tres nombres para orar específicamente por ellos.

El periodo de oración será determinado de acuerdo a cada caso, dependiendo de las circunstancias. Hay que recordar que este tipo de evangelismo lleva tiempo, sin embargo; las personas que son ganadas por la amistad y el compañerismo generalmente permanecen en la iglesia. ${ }^{1}$

Cuando ya se determinó quiénes son los tres nombres y se empezó a orar por

\footnotetext{
${ }^{1}$ Oosterwal, 41, 42.
} 
ellos, entonces se realiza algunas actividades para fomentar la confianza y la amistad. Una esas actividades puede ser: mandar una tarjeta de cumpleaños, pedir un favor, hacer un favor, aceptar alguna invitación, invitar a comer, visitar si está enfermo, felicitar por algún evento importante, saludar amablemente cuando está a nuestro paso o llamar por teléfono para desear éxito en sus actividades.

Siendo que la confianza y la amistad son muy frágiles, una vez que se ha establecido la relación amistosa, se debe tener cuidado para no sorprender a la persona hablándole de religión. Después que la amistad se ha fortalecido durante un tiempo, y el miembro de la iglesia ha demostrado que es un cristiano por su manera de vivir, entonces ha llegado el momento para compartir con el interesado algunos detalles de la religión. Por ejemplo: invitarlo a alguna reunión de la iglesia, regalarle una Biblia, preguntarle si desea puede orar por él por algún problema que tenga, decirle que usted es cristiano y que pertenece a la Iglesia Adventista, contarle alguna experiencia espiritual, o lo que venga a las circunstancias.

Cuando la persona está interesada en conocer la religión, entonces se puede iniciar el estudio de la doctrina. Al final de los estudios la decisión para aceptar a Jesús es obra del Espíritu Santo en la mente y corazón de la persona.

Después de un mes el instructor se reúne de nuevo con el grupo que tomó el curso para evaluar los resultados obtenidos. De ser posible el instructor acompaña a algunos de los participantes para saludar a sus amigos.

\section{Evaluación}

Para observar los resultados de este programa, se programarán cuatro evaluaciones en las siguientes modalidades: una al inicio, otra al término de cada sesión, 
otra al final de todas las sesiones y la última será para evaluar todas las partes del programa.

\section{Evaluación antes de iniciar}

El instructor hará una evaluación a los participantes al inicio del programa, para conocer el nivel de conocimiento de los participantes. Dicha evaluación será relacionada con los aspectos del programa de manera general. Esto permitirá evaluar el avance obtenido al tomar el curso. Ver el formulario en el apéndice.

Evaluación del aprovechamiento

Al final de cada periodo de clases se hará una evaluación parcial del tema tratado. El instructor hará un repaso de los puntos más sobresalientes, enfatizando lo que espera sea recordado y aplicado.

Al terminar todo el programa, se aplicará una evaluación final, para conocer el aprovechamiento de los alumnos y compararlo con la evaluación inicial. Dichas evaluaciones serán aplicadas de manera general, lanzando las preguntas al grupo para que respondan de manera verbal.

\section{Evaluación del programa}

Con la finalidad de mejorar el programa, para que resulte más útil y aporte mayores beneficios a la iglesia, es necesario realizar al final una evaluación completa. Esta evaluación comprenderá el aspecto teórico en conocimientos que obtuvieron los participantes, como también lo practico que resultó para la iglesia.

Además se considera en qué medida se alcanzaron los objetivos generales propuestos en el programa. Dicha evaluación será realizada por el instructor o el pastor 
en los comentarios y opiniones de los participantes y sobre los resultados. 


\section{CAPÍTULO V \\ RESUMEN, CONCLUSIONES Y RECOMENDACIONES}

\section{Resumen}

La amabilidad es muy importante porque facilita las relaciones sociales y personales en a la sociedad. Esta cualidad se manifiesta en el trato cordial, en el uso de las palabras adecuadas, en la manera como se trata a las personas con las que se sociabiliza y en el concepto que se tenga de los demás. En la Biblia este concepto es muy usado y ejemplificado. En el idioma hebreo el término usado es jésed que significa bondad, amabilidad o gracia. Aparece 245 veces en los escritos del Antiguo Testamento, y se aplica mayormente a la bondad de Dios al manifestar sus atributos a favor de la humanidad (Ex. 34:6).

En el Nuevo Testamento el vocablo que se utiliza es epieikēs, y denota lo placentero, justo, y paciente. Además expresa una consideración humana y razonable de un asunto. En 1 Ti. 3:3, Stg. 3:17 y Tit. 3:2, entre otros, se traduce como amable.

Para los cristianos el ser amables es un resultado de su relación con Dios, que se muestra en una correcta consideración hacia los demás. Por lo tanto el mostrar un trato amable no depende de las circunstancias, sino es algo espontáneo como fruto del Espíritu Santo (Gá. 5:22, 23).

La amabilidad sincera sirve como base para establecer amistades. Bien orientada es un medio muy útil en la predicación del evangelio. En el desarrollo de la 
iglesia apostólica, la amistad fue utilizada como método para el esparcimiento del evangelio entre amigos y conocidos (Hch. 18:1-4, 7, 8, 24-27). El crecimiento cuantitativo y cualitativo se debió al compañerismo y la convivencia que existía entre los miembros de la iglesia de aquellos tiempos (Hch. 2: 44-47). Las iglesias del tiempo apostólico fueron establecidas en hogares como grupos de amistad (Ro. 16:5; 1Co. 16:19; Col. 4:15).

El método de la evangelización por medio de la amistad, requiere de tiempo. Es un proceso que no puede ser determinado por etapas porque tiene que ver con el grado de sinceridad al ofrecer amistad a las personas.

En la actualidad este modelo de evangelización sigue siendo efectivo, los estudios sobre el crecimiento de iglesia muestran que aproximadamente el 60 por ciento de los adultos bautizados en la Iglesia Adventista tuvo su primer contacto con la iglesia mediante familiares, amigos o vecinos adventistas.

El evangelismo de la amistad es una manera natural de proceder, aprovechando todas las oportunidades que se presentan para establecer una relación amistosa, usando términos amables y cristianos que preparen el ambiente para presentar el evangelio en el momento oportuno.

Las personas que entran a la iglesia por medio de las amistades, generalmente son miembros estables y se mantienen en fiel cumplimiento de los principios de la vida cristiana. Por tal razón, es necesario que en cada iglesia se realicen actividades para fomentar entre los miembros los principios correctos de amabilidad y de amistad cristiana que bien usados sirven de medio para alcanzar a los compañeros de trabajo, conocidos y personas con las cuales se trata cotidianamente

A fin de lograr estos objetivos se diseñó un seminario de seis horas para enseñar a 
los hermanos de iglesia para que puedan ser expuestos al evangelismo de la amistad. En el seminario se repasan las bases teóricas del tema y se plantean formas prácticas de implementar ese tipo de evangelismo. Los materiales para el seminario están en el apéndice de esta tesis.

\section{Conclusiones}

El análisis de las fuentes consultadas, como la Biblia, los escritos de Elena G. de White y otros autores permite concluir que:

La amabilidad es una virtud necesaria en las relaciones humanas para que exista un trato agradable entre los seres humanos, ya que la humanidad está formada de personas altamente sociables y que fueron creadas para vivir en sociedad ( $\mathrm{Gn}$. 2:18).

La verdadera amabilidad no está sujeta a circunstancias, lugar o condición social, sino que es la demostración natural de los principios que existen el ser humano, como resultado del conocimiento y comprensión de las necesidades de sus semejantes.

El origen de la genuina amabilidad se encuentra en Dios mismo. Ésta se manifiesta en la realización de actos bondadosos en favor de la humanidad. No importa cual sea la condición de la raza humana, Dios muestra su bondad para bien de todos (Mt. $6: 45)$.

La base para establecer amistad y compañerismo se encuentra en tratar a las personas con las cuales nos relacionamos frecuentemente de manera amable y con la debida consideración de sus sentimientos y necesidades.

La Biblia, como un libro de origen divino, presenta los principios correctos y necesarios para que exista una relación saludable entre los seres humanos y se produzca un ambiente agradable expresado en palabras y actos bondadosos. 
En el cumplimiento de la misión de la iglesia, el uso de la amabilidad constituye un factor importante que permite establecer relaciones amistosas para dar a conocer el evangelio.

La amabilidad y la amistad se pueden usar como medio de evangelismo, expresadas con palabras amables, con disposición al servicio a favor de los demás, y con una relación amistosa sincera.

El éxito en la evangelización por la amistad depende de una profunda y correcta relación personal con Dios. Nadie puede dar lo que no tiene. Para poder compartir con otros la verdad que se profesa es necesario que el amor de Cristo esté en nuestros corazones como parte de la vida.

\section{Recomendaciones}

Siendo que la amabilidad sincera produce relaciones amistosas que logran establecer buenas amistades, y que éstas pueden ser utilizadas como medio de evangelismo. Se recomienda.

\section{A las asociaciones o misiones:}

1. Que se capacite e instruya a los pastores acerca del método de evangelismo de la amistad y la manera de realizarlo siguiendo el programa de evangelización que se propone en esta tesis.

2. Que en cada asociación o misión se programe durante el año eclesiástico por lo menos una reunión de un fin de semana para dar a todos los pastores el seminario completo, y que en esa reunión cada pastor se comprometa a establecer en su distrito este programa. 
3. Que la administración de cada campo local, haga provisión para repartir de manera gratuita a cada pastor una copia del seminario de evangelización por la amistad.

4. Que se realicen reuniones por sectores de cada asociación o misión para capacitar a los ancianos y dirigentes de las iglesias sobre este tema.

5. Que se realice una buena promoción parte de la asociación o misión, antes de lanzar el programa a todo el campo, presentando los beneficios que ofrece esta manera de evangelizar por medio de la amistad.

6. Que en cada asociación o misión se realicen reuniones de pastores donde se fomente el compañerismo y la amabilidad y que hagan actividades en grupos para fortalecer la amistad entre el equipo ministerial.

\section{A los distritos:}

1. Que en cada distrito se realice este seminario y que el instructor sea el pastor distrital o algún invitado de la asociación o algún laico capacitado, a fin de que la mayoría de los miembros reciban el curso.

\section{A las iglesias:}

1. Que en cada iglesia sea impartido este seminario por algún anciano capacitado para ello, o el pastor, y de esta manera todos los miembros puedan conocer este plan.

2. Que antes de realizar el seminario se aplique la evaluación que se encuentra en el apéndice de esta tesis.

3. Que se preparen programas en las iglesias sobre la amabilidad y la amistad para capacitar a los miembros para tratar bien a las visitas que asisten a la iglesia, y entre ellos mismos. 
APÉNDICE

SEMINARIO 


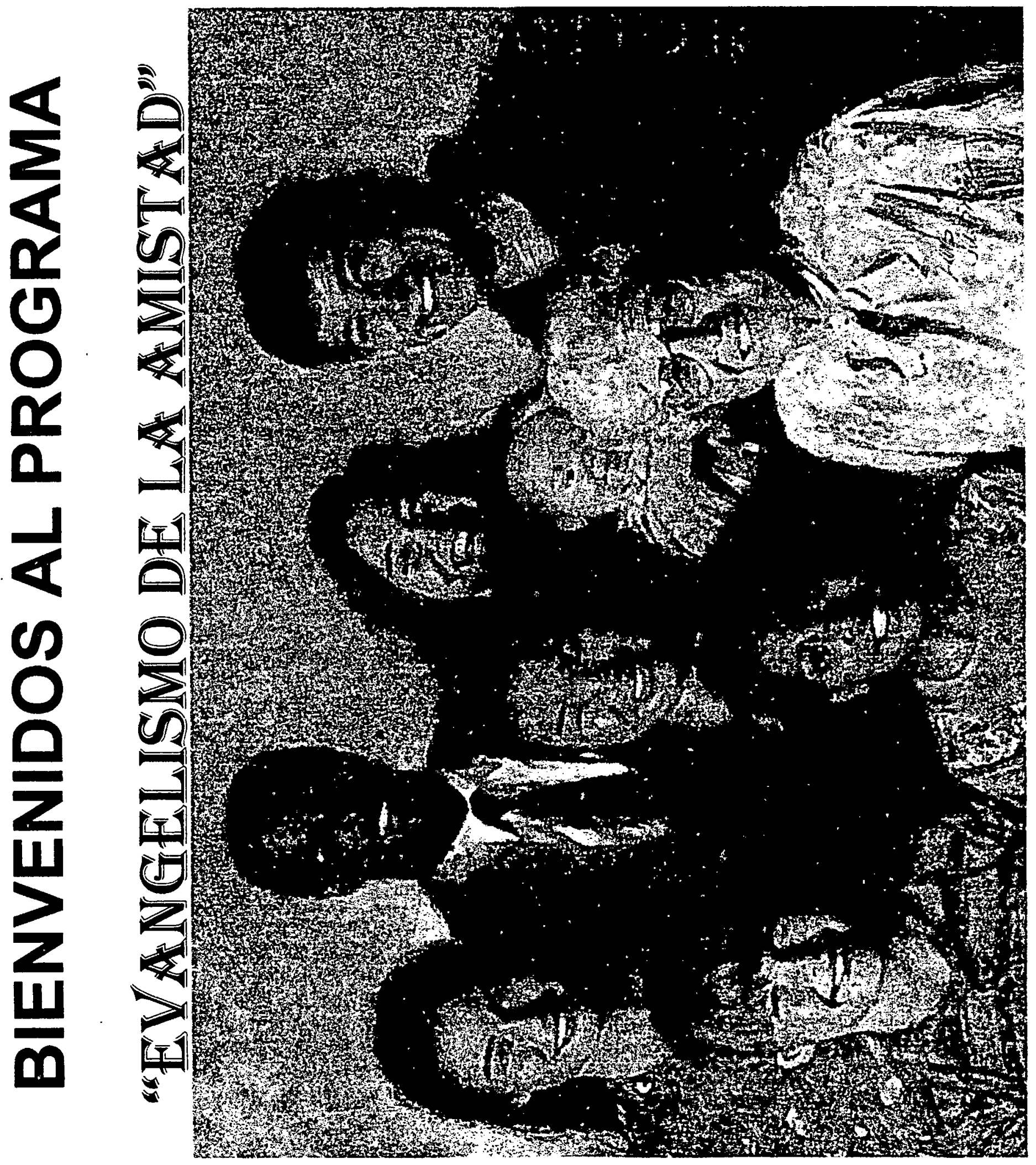




\section{PROPÓSITO}

¿l propósito de este programa es capacitar a los miembros y dirigentes de la iglesia, para mostrar amabilidad y buen trato en las relaciones personales. Y de esta manera establecer amistad con vecinos, compañeros de trabajo, conocidos y otros, para prepararlos para la aceptación del evangelio 


\section{OBJETIVOS}

1. Ofrecer información acerca del evangelismo de la amistad.

2. Instruir a los participantes en los principios básicos de la evangelización por medio de la amistad.

3. Enseñar a los miembros de la iglesia cómo ser más amables con sus semejantes. 


\section{OBJETIVOS}

4. Enseñar a los miembros de la iglesia maneras prácticas de evangelizar por medio de la amistad.

5. Motivar a los miembros de la iglesia a participar en la predicación del evangelio por medio de la amistady las buenas relaciones personales. 


\section{INTRODUCCIÓN}

La Iglesia Adventista, en el fiel cumplimiento de su misión, ha utilizado diferentes métodos para evangelizar obteniendo diversos resultados.

Elevangelismo de la amistad ha demostrado ser un método útil en la predicación. Sin embargo éste método ha sido poco utilizado en la iglesia. 


\section{¿Qué es evangelizar?}

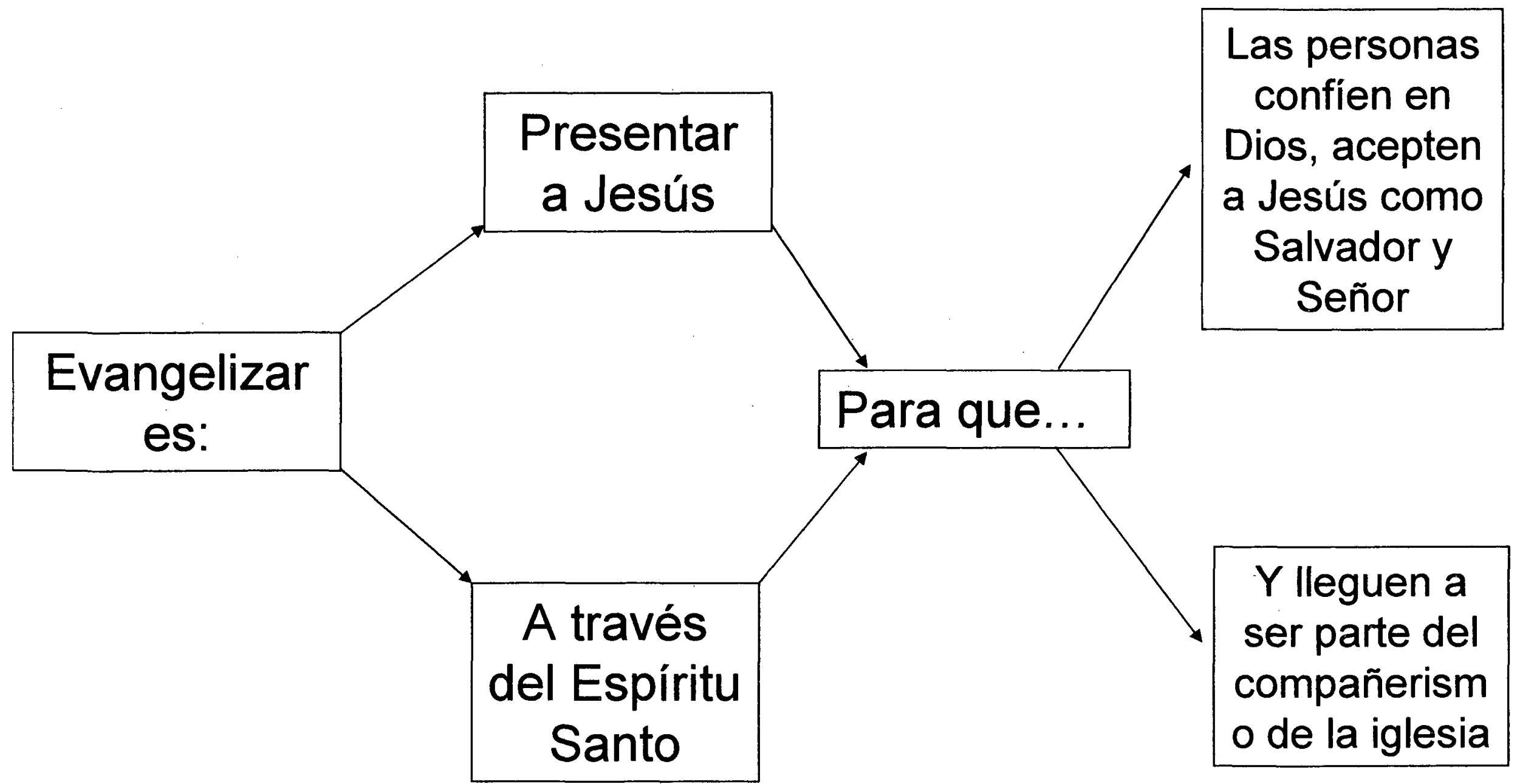




\section{SESIÓN 1}

\section{Maneras para evangelizar}

\section{Cumpliendo el mandato divino}

\section{Ministerio de la salud}

\section{Evangelismo por el estilo de vida}

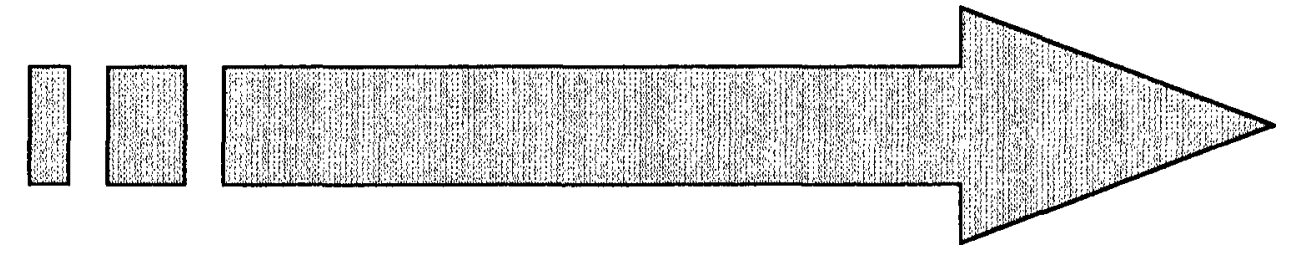

\section{Testimonios personales}

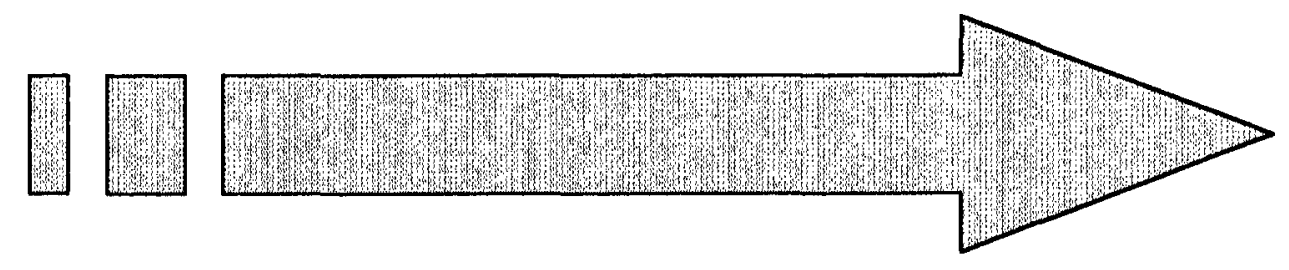




\section{Evangelismo por la música}

\section{Ministerio de publicaciones}

\section{Evangelismo público}

Evangelismo por la amistad 

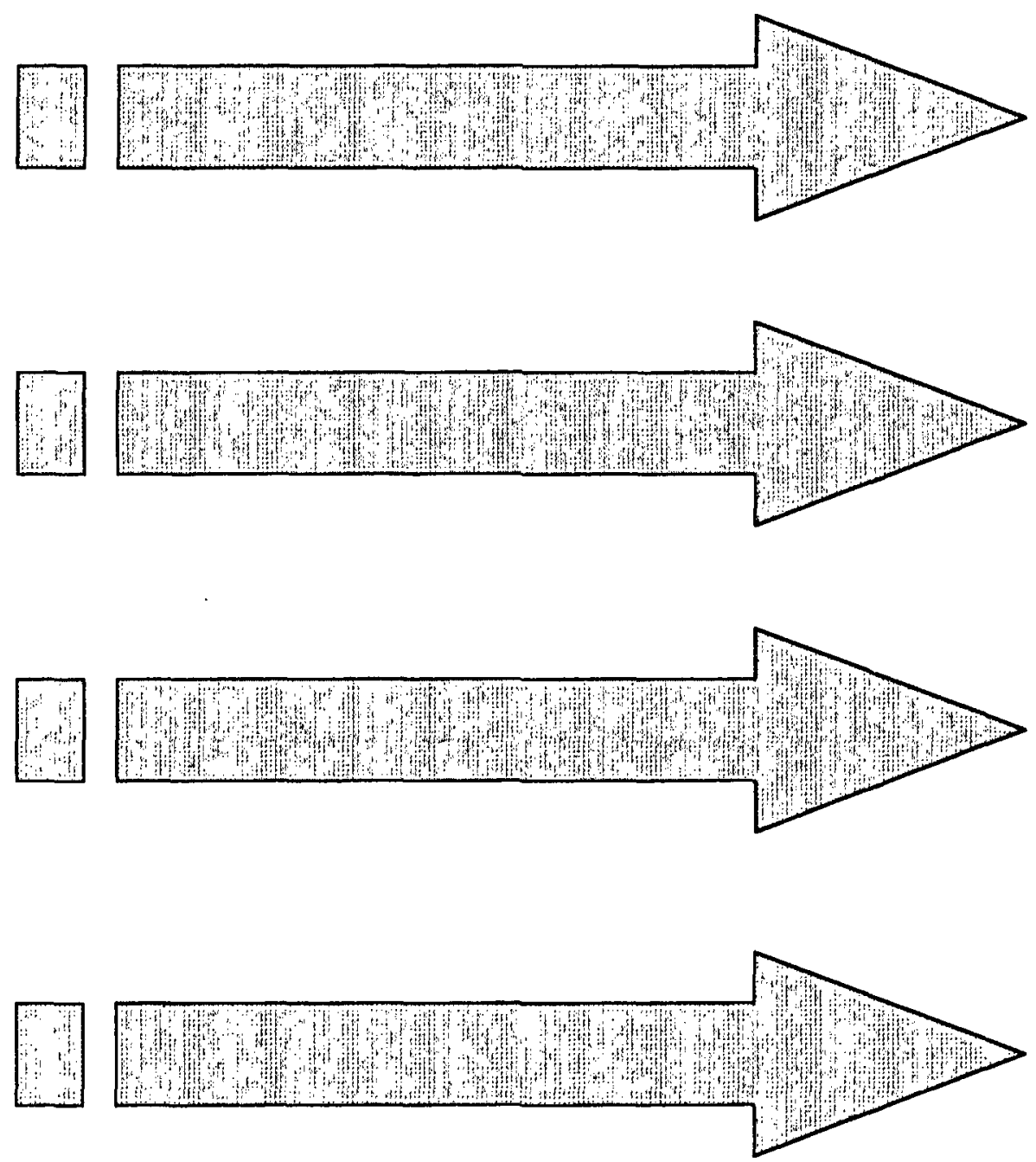


\section{Definiciones de "Evangelismo de la amistad"}

Es la manera práctica de compartir el

lenguaje de la ayuda con las personas

que nos rodean, y hacerle saber que

Dios las ama. 


\section{Definiciones de "Evangelismo de la amistad"}

Es una forma natural de proceder aprovechando todas las oportunidades que se abren de por si y hablar en términos amables y cristianos, que dejen la puerta abierta para establecer una amistad, y luego evangelizar. 


\section{Definiciones de "Evangelismo de la amistad"}

Es un proceso por el cual se logra un tipo de relación positiva y favorable que permite establecer el fundamento para que exista una amistad verdadera, que prepara el corazón de las personas para presentar el evangelio. 


\section{Elena G. de White y el Evangelismo de la amistad}

"Si quisiéramos humillarnos ante Dios, ser amables, corteses y compasivos, se producirían cien conversiones a la verdad allí donde se produce una ahora" $\mathcal{M} B$, 127.

"El poder de la sociabilidad, santificado por el Espíritu de Cristo debe mejorar a fin de ganar almas para el Salvador", MCP, 2:648. 


\section{Elena G. de White y el Evangelismo de la amistad}

“Son las palabras agradables y llenas de simpatía, la manifestación del amor desinteresado por las almas, lo que romperá la barrera del orgullo y del egoísmo y mostrará a los incrédulos que poseemos el amor de Cristo; y entonces la verdad se abrirá camino al corazón",

Ev., 462. 


\section{La Biblia y el evangelismo de la amistad}

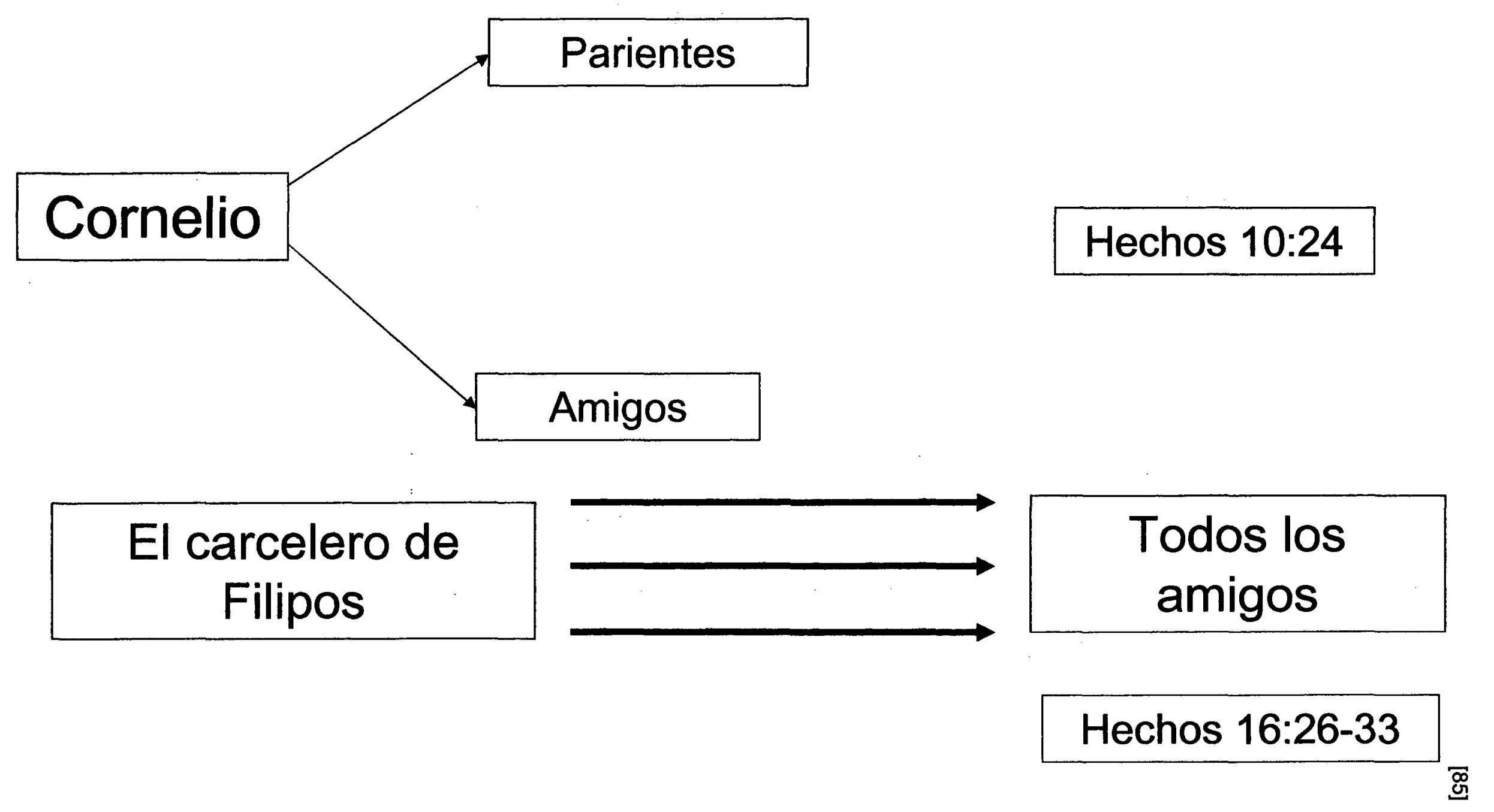




\section{Juan 1:40-51}

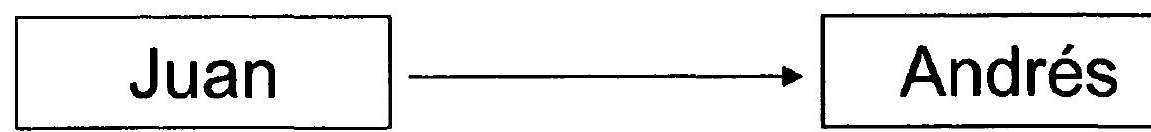

Jesús

Felipe

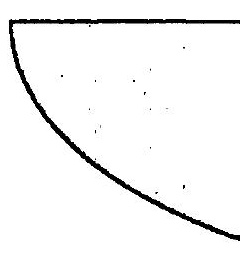




\section{Una iglesia amistosa y evangelizadora}

Hechos 18

Vers 1-3, Pablo estableció relaciones de amistad con

Aquila y Priscila

Vers. 7, 8, Pablo estableció una iglesia en el hogar de su amigo Justo. Esa iglesia del hogar atrajo a Crispo, el jefe de la sinagoga, y a muchos otros.

Vers. 19, 24-27, Pablo dejó a Priscila y Aquila en Éfeso. Ellos hicieron amistad con Apolos, le llevaron a su hogar y le enseñaron acerca de Cristo. Apolos conmovió a Corinto y compartió las buenas nuevas que Priscila y Aquila le habían dado. 


\section{Rom. 16: 3,5. Aquila y Priscila se trasladaron más tarde a Roma y establecieron una iglesia amigable en su propio domicilio}

En el proceso por el cual el conocimiento de Cristo se esparció desde Jerusalén hasta Roma, el trabajo en cadena, fue uno de los más importantes factores de influencia 
Modelo de evangelización por amistad y parentesco

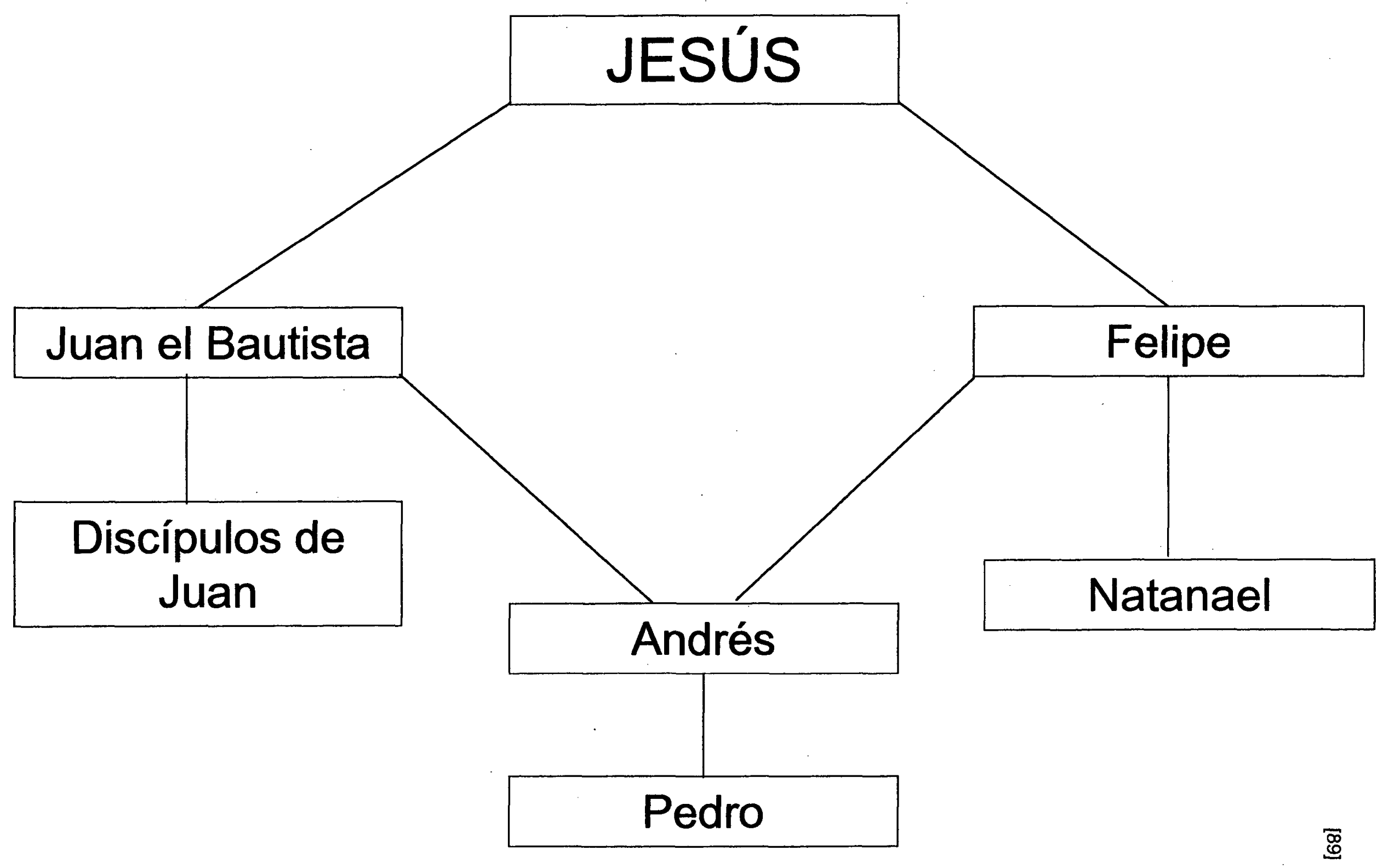




\section{Cómo ganar amigos \\ Principios prácticos}

1. Trate a todos amablemente

7. Acepte a todos como son

2. Sea sincero

8. Acéptese a usted mismo

3. Respete a todos

4. Sonría

9. Sea un buen vecino

5. Esté dispuesto a servir a los

10. Ore mucho a Dios por demás

cada uno de sus conocidos

6. Busque la oportunidad de ser

útil a otros 


\section{TAREA No. 1}

\section{Para estudiar, meditar y comentar}

¿Qué nos dicen los siguientes textos 6íblicos respecto de la clase de cuidado que debemos tener para ejercer una influencia positiva y poderosa?

Jeremías $31: 3$

Cantares 8:7

1a Corintios 13:8, 13

Lucas 15:11-23, 32 


\section{SESIÓN 2}

Base bíblica

Proverbios 18:24

Juan 15:15

Lucas 10:36, 37

1a. Pedro 3

Filipenses 2:5-11
El que tiene amigos debe mostrarse amigo

Os he llamado amigos

El samaritano uso misericordia con él

Sed todos amigables

Ejemplo perfecto de bondad y amabilidad 


\section{Base del Espíritu de profecía}

Mediante las relaciones sociales es como el cristianismo se transmite al mundo, Manuscrito 59, 1897.

Por medio del trato social se contraen relaciones y se forman amistades que unen los corazones y crea un ambiente de amor que agrada al cielo, TCh, 7:172.

Visitad a vecinos de una manera amigable y trabad relaciones con ellos, MB, 83

Id a vuestros vecinos visitándolos uno por uno y acercaos a ellos hasta que sus corazones sean calentados por vuestro interés y vuestro amor abnegado, SC, 145. 


\section{El compañerismo y amistad de la Iglesia Apostólica}

Los miembros se reunían en casas, Romanos 16:5.

Se practicaba una religión relacional, 1a. Corintios 16:19, 20.

Estaban unidos en todas las cosas, $\mathcal{H}$ echos 2:44, 47.

Las casas eran usadas como templos, Colosenses 4:15

Velaban unos por otros, Colosenses 4:12-15. 
Koinonia y evangelismo de la amistad

Koinonia significa comunión, compañerismo, participación en común (koinos = común), CBA, 6:885.

Pablo utiliza el término en Gálatas 2:9

Pedro enfatiza la koinonia, 1a. Pedro 3:8

Una iglesia amistosa cultiva el compañerismo, fomenta la unidad y realiza trabajo misionero.

Vive en comunión con el Espíritu Santo, 2a. Corintios 13:14.

Koinonia aparece 20 veces en el Nuevo Testamento 


\section{TAREA No. 2}

Para estudiar, meditar y comentar

Leer detenidamente el capítulo "Los modales" del libro La educación, págs. 240242.

Responder a las siguientes preguntas:

1. ¿Cuál es la esencia de la verdadera cortesía?

2. ¿Cuál es la cultura que es un fracaso?

3. ¿Quién es la fuente de la verdadera cortesía? 


\section{SESIÓN 3}

Importancia de la amabilidad para el evangelismo de la amistad

¿Qué es amabilidad?

Es un código de conducta que se manifiesta espontáneamente en palabras y actitudes bondadosas hacia nuestros semejantes. Annne-Marie de vilaine, sin temor a equivocarse, 42

Es una gracia del Espíritu, que tiene poder para suavizar la naturaleza del hombre en su trato con los demás. oE, 127.

La esencia de la verdadera cortesía, es la consideración hacia los demás. Ed., 236. 


\section{ANTIGUO TESTAMENTO}

En hebreo Jésed se traduce como bondad, amabilidad o gracia. Aparece 245 veces en el Antiguo Testamento. Se aplica mayormente a Dios, como una manifestación de sus atributos (Éxodo 36:6,7)

Ejemplos de actos amables

José y sus hermanos (Gén. 50:19, 21)

Moisés y las hijas del sacerdote de Madián (Ex. 2:17)

David y mefiboset (2 Sam. 9:3-7)

Abigail y David (1 Sam. 25:12-35 
NUEVO TESTAMENTO

Amabilidad

1 Timoteo 3:3

Tito $3: 2$

Santiago 3:17

Filipenses 4:5

Placentero, agradable, amable

Filipenses 4:8

2 Timoteo 2:24

1 Tesalonicenses 2:7 
La amabilidad en los escritos de Pablo

Romanos 12:18

"Si es posible, en cuanto dependa de vosotros, estad en paz con todos los hombres"

Efesios 4:29

"Ninguna palabra corrompida salga de vuestra boca, sino la que sea buena para la necesaria adificación, a fin de dar gracias a los oyentes"

Colosenses 4:6

"Sea vuestra palabra siempre con gracias, zasonada con sal, para que sepáis cómo debéis responder a cada uno"

$\overline{\mathrm{\sigma}}$ 


\section{Elena G. de White y la amabilidad}

El cultivo de una cortesía uniforme, la voluntad de tratar como desearíamos ser tratados nosotros, eliminaría la mitad de las dificultades de la vida, MB, 161.

El principio de ser "sinceramente amables unos a otros" llega a ser el fundamento necesario para vivir en sociedad, $\mathrm{FAH}, 161$

La esencia de la verdadera cortesía es la consideración hacia los demás, Evang., 462 


\section{TAREA No. 3}

Para estudiar, meditar y comentar

Lea en Marcos 3:13-15 y encuentre tres elementos básicos que Jesús utilizó en la preparación de sus discípulos:

1.

2.

3. 


\section{SESION 4}

Preparación espiritual.

1. Nuestra relación con Dios:

"Aunque hemos de trabajar fervorosamente para la salvación de los perdidos, también debemos tomar tiempo para la meditación, la oración y el estudio de la Palabra de Dios", DTG, 329.

2. Guiados por su Espíritu

"Necesitamos clarividencia espiritual para poder ver los designios del mensaje, y proclamar el peligro como fieles centinelas", OE, 306. 
3. Con el poder del Espíritu Santo

"Pero recibiréis poder cuando haya venido sobre vosotros el espíritu Santo, y me seréis testigos en Jerusalén, en toda Judea, en Samaria y hasta lo último de la tierra", Hch. 1:8 


\section{TAREA No. 4}

Leer en el DTG el capítulo 58, "Lázaro ven fuera”, págs. 482-494.

Las preguntas se harán la próxima clase.

Traer por escrito el nombre completo de tres de sus conocidos y un motivo de oración por cada uno. 


\section{SESIÓN 5}

Maneras prácticas para evangelizar por medio de la amistad:

1. Ore a Dios por un amigo especial

"En todas partes hay corazones que claman por algo que no poseen, suspiran por una fuerza que les dé dominio sobre el pecado, una fuerza que los libre de la esclavitud del mal, una fuerza que les dé vida", MC, 102

2. Cultive su amistad

"Al hombre que tiene amigos ha de mostrarse amigo" (Prov. 18:24)

*Envíe una tarjeta el día de su cumpleaños

*Comparta sus momentos de alegrías

*Salúdelo sinceramente 
3. Acepte sus invitaciones

Cristo no rehusó mezclarse con otros en amable trato, MPS, 404.

"Aceptaba las invitaciones de uno y de otros, asistía a sus banquetes, se familiarizaba con sus intereses y ocupaciones para abrirse camino a sus corazones y darles a conocer las riquezas imperecederas", MC, 15.

La aceptación y la asistencia a las reuniones de nuestras amistades no debe poner en riesgo nuestros principios.

4. Escuche atentamente

No es posible ayudar a las personas a llevar sus cargas sin estar dispuestos a escucharlas en sus necesidades.

Escuchar con atención requiere disciplina.

Escuchar no es sólo oír.

Saber escuchar tiene aspectos maravillosos en las relaciones

C. Osborne, Llevarse bien es un arte, 32. 
5. Sea positivo y alegre

"Hay misteriosos vínculos que ligan las almas, de manera que el corazón de uno responde al del otro", MPJ, 409.

6. Pida un favor

Ejemplo de Jesús y la mujer samaritana (Juan 4:7)

"El odio que reinaba entre los judíos y los samaritanos impidió a la mujer ofrecer un favor a Jesús, pero el Salvador estaba tratando de hallar la llave de su corazón, y con el tacto nacido del a amor divino, él no ofreció un favor, sino que lo pidió", DTG, 155-156.

7. Sea honesto y sincero

No deben utilizar máscaras para esconder la verdadera identidad. Debe haber libertad para que la persona se muestre tal cual es. 
8. Cumpla fielmente sus compromisos

El sentido de responsabilidad enaltece al individuo y lo hace digno de confianza. Ésta cualidad en las relaciones humanas determina el grado de credibilidad que se le puede otorgar a una persona.

Carlos Tornero, La actitud del hombre frente a la vida, 81.

"Mejor es que no prometas, y no que prometas y no cumplas", (Ecl. 5:5) 


\section{CONCLUSIÓN}

"Sólo el método de Cristo será el que dará éxito para llegar a la gente. EI Salvador trataba con los hombres como quien deseaba hacerles bien. Les mostraba simpatía, atendía sus necesidades y se ganaba su confianza.

Entonces les decía: Seguidme", MC, 102.

\section{¡Evangelismo de la amistad!}

\section{Usted puede hacerlo.}

Su familia puede participar.

\section{Su iglesia también.}

Entonces, hagámoslo. 


\section{PROGRAMA DE EVANGELISMO DE LA AMISTAD}

\section{EVALUACIÓN}

Conteste las siguientes preguntas marcando con un Sí o un No la respuesta correcta

1. ¿Sabe usted qué es evangelismo de la amistad?

2. ¿Ha asistido usted a algún seminario de evangelismo?

3. ¿Conoció usted la Iglesia Adventista por algún pariente o amigo?

4. ¿Tiene usted amigos que no son adventistas?

5. ¿Tiene usted compañeros de trabajo que no son adventistas?

6. ¿Considera usted que la amistad puede ser un medio para evangelizar?

7. ¿Conoce usted a algún miembro de iglesia que fue ganado por un amigo

8. ¿Considera usted a la Iglesia Adventista como una iglesia amistosa?

9. ¿Tiene usted amigos dentro de la iglesia?

10. ¿Se siente usted a gusto con la manera como lo tratan en la iglesia? 
BIBLIOGRAFÍA 


\section{BIBLIOGRAFÍA}

Aalder, G. Charles. The Book of Genesis. Grand Rapids: Zondervan, 1981.

Aguado Soria, Victor. Cortesía y distinción. Barcelona: Sintes, 1961.

Alan C., Filley. Solución de conflictos interpersonales. México, D.F.: Trillas, 1991.

Alonso, Martín. Diccionario de sinónimos explicados. Madrid: Edaf, 1984.

Arn, Win, y Charles Arn. El plan del maestro para hacer discipulos. Pasadena: Church Growth, 1982.

Arndt, Willian F., y F. Wilbur Gingrich. A Greek-English Lexicon of the New Testament and Other Early Christian Literature. Chicago: University of Chicago Press, 1957.

Ayala, Vidal. Pastoral y evangelización de jóvenes. Madrid: ICCE, 1977.

Bakke, Ray, y Jim Hart. The Urban Christian. Downers Grove: InterVarsity, 1987.

Barber, Cyril J. Nehemías: Dinámica de un líder. Miami: Vida, 1976.

Barna, George. User Friendly Churches. Ventura, CA: Regal, 1991.

Bauer, Johannes B. Diccionario de teologia biblica. Barcelona: Herder, 1967.

Bullón, Alejandro. A solas con Jesús. Buenos Aires: Casa Editora Sudamericana, 1998.

Clarke, Adam. Comentario de la Santa Biblia. Kansas City, MO: Casa Nazarena, 1980.

Comentario bíblico adventista. 7 vols. Editado por F. D. Nichol. Traducido por V. Ampuero Matta. Boise: Publicaciones Interamericanas, 1978-1990.

Comiskey, Joel. La explosión de los grupos celulares en los hogares. Terrassa, Barcelona: CLIE, 2000.

Cuyás, Arturo. Hace falta un muchacho. México, D. F.: Universo, 1989. 
Diccionario de la lengua española. Madrid: Espasa-Calpe, 1992.

Diccionario enciclopédico Quillet. México, D. F.: Cumbres, 1988.

Elliott, John H. I-II Peter. Augsburg Commentary on the New Testament. Minneapolis: Augsburg, 1982.

Enciclopedia de la Biblia. 6 vols. Barcelona: Garriga, 1963.

Filley, Alan C. Solución de conflictos interpersonales. México, D. F.: Trillas, 1991.

Fingermann, Gregorio. Relaciones Humanas. México, D. F.: El Ateneo, 1982.

Flores, Juan. El libro de oro de la cortesía. Barcelona: Juan Pueyo, 1967.

Flowers, Ron, y Karen Flowers. Amor rebosante. Miami: Asociación Publicadora Interamericana, 1992.

Gillespie, V. Bailey. Sabios para la salvación. Buenos Aires: Asociación Editora Sudamericana, 1995.

Griffiths, David N. Implementando la calidad. México, D. F.: Panorama, 1992.

Harrison, Everett F., ed. Diccionario de teología bíblica Moody. Chicago: Moody, 1971.

Holt, Russell. Sabiduría para vivir. Miami: Casa Publicadora Interamericana, 1991.

Horn, Siegfried, H. Diccionario biblico adventista. Buenos Aires: Casa Editora Sudamericana, 1995.

Jenni, Ernst. Diccionario teológico manual del Antiguo Testamento. Madrid: Cristiandad, 1978.

Keough, G. Arthur. Alegrémonos con el salmista. Miami: Asociación Publicadora Interamericana, 1995.

Keyes, Kenneth S. Como desarrollar su habilidad mental. México, D. F.: Trillas, 1966.

Martín, Carlos. Como trastornar al mundo. Buenos Aires: Casa Editora Sudamericana, 2000.

Maxwell, Graham. Siervos o amigos. Redlands: Pineknoll, 1992.

Maxwell, Randy. Si mi pueblo orara. Miami: Asociación Publicadora Interamericana, 2000. 
McPhee, Arthur G. Friendship Evangelism: The Caring Way to Share Your Faith. Grand Rapids: Zondervan, 1978.

Oosterwal, Gottfried. Patterns of SDA Church Growth in North America. Berrien Springs: Andrews University Press, 1974.

Osborne, Cecil G. Llevarse bien es un arte. Miami: Vida, 1983.

Pereyra, Suárez Hector. ¿Qué quieres que haga? Miami: Asociación Publicadora Interamericana, 2001.

Pradas, Jorge. Congregados para darle gloria. Terrassa, Barcelona: CLIE, 1986.

Pradel, Henri. Educación de la cortesía. México, D. F.: Ediciones Paulinas, 1959.

Rittenhouse, Floyd O. Muéstrame tus caminos. Miami: Interamerican Publishing Association, 1983.

Rhode, Naomi. El don de la amistad. México, D. F.: Selector, 1991.

Rice, George, E. Una esperanza viva. Buenos Aires: Casa Editora Sudamericana, 1992.

Rinker, Rosalind, y Harry C. Griffith. Compartiendo el amor de Dios. Terrassa, Barcelona: CLIE, 1976.

Rittenhouse, Floyd O. Muéstrame tus caminos. Miami: Interamerican Publishing Association, 1983.

Sahlin, Monte. Friendship Evangelism. Siloam Springs: Concerned Comunications, 1990.

Schwarz, Christian A. Desarrollo natural de la iglesia. Terrassa, Barcelona: CLIE, 1986.

Seventh-day Adventist Encyclopedia. Edición revisada. 2 vols. Hagerstown, MD: Review and Herald, 1996.

Skinner, B. F. Más allá de la libertad y la dignidad. Barcelona: Martínez Roca, 1986.

Tornero Díaz, Carlos. La actitud del hombre frente a la vida. Buenos Aires: Porrúa, 1991.

Van Dolson, Leo. El Dios que habla y muestra. Buenos Aires: Casa Editora Sudamericana, 1998.

Van Pelt, Nancy. Sin reservas: El arte de comunicarse. Madrid: Safeliz,1996. 
Vilaine, Anne-Marie de. Sin temor a equivocarse. México, D. F.: Selecciones del Readers Digest, 1978.

Vine, W. E. Diccionario expositivo de palabras del Nuevo Testamento. Terrassa, Barcelona: CLIE, 1984.

Von Allmen, Jean-Jacques. Vocabulario biblico. Madrid: Morora, 1968.

Vos, Howard, F. 1, 2 Samuel. Bible Study Comentary. Grand Rapids: Zondervan, 1983.

Watts, Dorothy Eaton. El don de la amistad. Miami: Asociación Publicadora Interamericana, 1995.

Weil, Pierre G. Relaciones humanas en el trabajo y la familia. Buenos Aires: Kapelusz, 1965.

Welter, Paul. Cuando tu amigo te necesita. Miami: Unilit, 1990.

Wheeler, Gerald. Sabiduría tesoro inagotable. Miami: Asociación Publicadora Interamericana, 2000.

White, Elena G. de. El camino a Cristo. Mountain View, CA: Publicaciones Interamericanas, 1979.

. Carta 6, 14 de enero de 1899, dirigida a los hermanos reunidos en el congreso anual de Sunnyside, Cooranbong, Australia. Centro White, Universidad de Montemorelos, N. L., México.

. Carta 324, 3 de octubre de 1907, dirigida a un administrador. Centro White, Universidad de Montemorelos, N. L., México.

. Consejos sobre la obra de la escuela sabática. Buenos Aires: Casa Editora Sudamericana, 1954.

. El Deseado de todas las gentes. Mountain View, CA: Publicaciones Interamericanas, 1955.

. La educación. Mountian View: Publicaciones Interamericanas, 1958.

. El evangelismo. Mountain View, CA: Publicaciones Interamericanas, 1976.

. Felicidad y armonía en el hogar. Mountain View, CA: Publicaciones Interamericanas, 1975.

. Manuscrito 59, 1897. Centro White, Universidad de Montemorelos, N. L., México. 
White, Elena G. de. Maranata: El Señor viene. Mountain View, CA: Publicaciones Interamericanas, 1976.

. La maravillosa gracia de Dios. Mountain View, CA: Publicaciones Interamericanas, 1973.

. Mensajes para los jóvenes. Mountain View, CA: Publicaciones Interamericanas, 1977.

. Mente, cáracter y personalidad. Buenos Aires: Casa Editora Sudamericana, 1990.

. El ministerio de curación. Mountain View, CA: Publicaciones Interamericanas, 1975.

. El ministerio de la bondad. Mountain View, CA: Publicaciones Interamericanas, 1977.

. Obreros evangélicos. Mountain View, CA: Publicaciones Interamericanas, 1974.

. El otro poder. Buenos Aires: Casa Editora Sudamericana, 1996.

- Reflejemos a Jesús. Buenos Aires: Casa Editora Sudamericana, 1985.

. Servicio cristiano eficaz. Mountain View, CA: Publicaciones Interamericanas, 1973. 1948.

Testimonies for the church. 9 vols. Mountain View, CA: Pacific Press,

Wilson, Margery. The Pocket Book Etiquette. New York: Pocket Book, 1941.

Zackrison, James W. Poder para testificar. Buenos Aires: Casa Editora Sudamericana, 1993. 


\section{CURRÍCULUM VÍTAE}

Tomás Torres de Dios (1959-

Fecha de ordenación: 5 de diciembre de 1991

EDUCACIÓN:

1986 Licenciatura en Teología, Universidad de Montemorelos, Nuevo León,

1995 Maestría en Religión (MA) Andrews University, extensión Montemorelos,

2002 Doctor en Ministerio, Andrews University, extensión Montemorelos

FUNCIONES DENTRO DE LA IGLESIA ADVENTISTA DEL SÉPTIMO DÍA

1986-1991 Pastor de distrito en la Asociación de Tabasco

1991-1995 Departamental en la Misión del Soconusco

1995-1999 Secretario de la Asociación de Tabasco

1999- Presidente de la Asociación del Mayab 